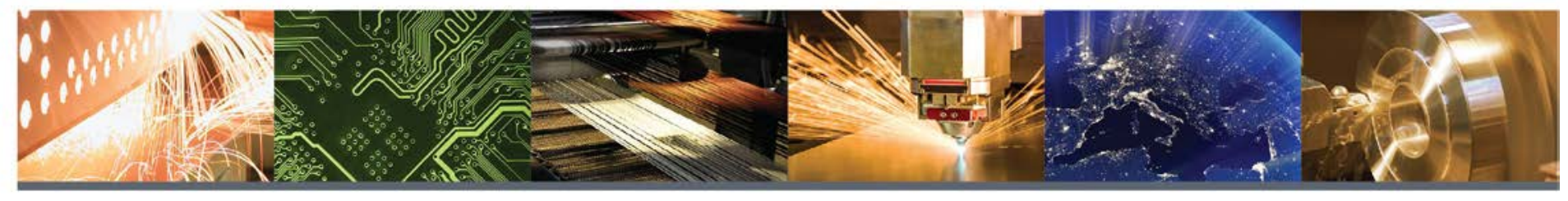

\title{
Critical Material Supply Chain Analysis: Magnetocalorics
}

Chuck Booten, Margaret Mann National Renewable Energy Laboratory

Ayyoub Momen, Omar Abdelaziz Oak Ridge National Laboratory

CEMAC is operated by the Joint Institute for Strategic Energy Analysis for the U.S. Department of Energy's Clean Energy Manufacturing Initiative.

Technical Report

NREL/TP-5500-75163

March 2020

Contract No. DE-AC36-08GO28308 


\section{Critical Material Supply Chain Analysis: Magnetocalorics}

Chuck Booten, Margaret Mann National Renewable Energy Laboratory

Ayyoub Momen, Omar Abdelaziz Oak Ridge National Laboratory

Prepared under Task No. BE4E.MA01

CEMAC is operated by the Joint Institute for Strategic Energy Analysis for the U.S. Department of Energy's Clean Energy Manufacturing Initiative.

Clean Energy Manufacturing Analysis Center 15013 Denver West Parkway

Golden, CO 80401

303-275-3000

\section{Technical Report}

NREL/TP-5500-75163

March 2020

Contract No. DE-AC36-08GO28308 


\section{NOTICE}

This report was prepared as an account of work sponsored by an agency of the United States government. Neither the United States government nor any agency thereof, nor any of their employees, makes any warranty, express or implied, or assumes any legal liability or responsibility for the accuracy, completeness, or usefulness of any information, apparatus, product, or process disclosed, or represents that its use would not infringe privately owned rights. Reference herein to any specific commercial product, process, or service by trade name, trademark, manufacturer, or otherwise does not necessarily constitute or imply its endorsement, recommendation, or favoring by the United States government or any agency thereof. The views and opinions of authors expressed herein do not necessarily state or reflect those of the United States government or any agency thereof.

Available electronically at SciTech Connect: http:/www.osti.gov/scitech

Available for a processing fee to U.S. Department of Energy and its contractors, in paper, from:

U.S. Department of Energy

Office of Scientific and Technical Information

P.O. Box 62

Oak Ridge, TN 37831-0062

OSTI http://www.osti.gov

Phone: 865.576 .8401

Fax: 865.576.5728

Email: reports@osti.gov

Available for sale to the public, in paper, from:

U.S. Department of Commerce

National Technical Information Service

5301 Shawnee Road

Alexandria, VA 22312

NTIS http://www.ntis.gov

Phone: 800.553 .6847 or 703.605 .6000

Fax: 703.605.6900

Email: orders@ntis.gov

Cover Photos: (left to right) iStock 2225189; iStock 16687273; Oak Ridge National Laboratory; iStock 24304597; iStock 26005993; iStock 2069560

NREL prints on paper that contains recycled content. 


\section{Acknowledgments}

This work was funded through the U.S. Department of Energy Building Technologies Office. The authors would like to thank Karma Sawyer and Antonio Bouza of the U.S. Department of Energy for their support of the project. Billy Roberts (National Renewable Energy Laboratory) was instrumental in creating several of the graphics in this report as well. 


\section{List of Acronyms}

AC

ARPA

DOE

EPA

EV

HDD

JARN

$M C$

MCR

$\mathrm{NiMH}$

RE

REE

REO

REPM

TREO

USGS air conditioner

Advanced Research Projects Agency-Energy

U.S. Department of Energy

U.S. Environmental Protection Agency

electric vehicle

hard disk drive

Japan Air Conditioning, Heating and Refrigeration News

magnetocaloric

magnetocaloric refrigeration

nickel metal hydride

rare earth

rare earth element

rare earth ore

rare earth permanent magnet

total rare earth oxide

United States Geological Survey 


\section{Executive Summary}

Understanding the manufacturing cost and supply chain implications of technologies is critical to aiding adoption of next-generation energy solutions, such as advanced heating ventilation and air conditioning equipment for building energy efficiency. This report provides insights into the market, regulatory, technology, and cost drivers that most impact the adoption of magnetocaloric refrigeration (MCR) systems in the United States. It focuses on the rare earth materials requirements, manufacturing costs of key components, and details about the supply chain of critical materials. The key objectives of this report are to:

- Identify key factors driving rare earth element (REE) production, processing, and downstream product manufacturing decisions, including locations of rare earth deposits

- Identify current and emerging REE end uses with a focus on clean technologies and provide an understanding of the surrounding market landscape

- Identify research, development, and demonstration needs at points along the value chain

- $\quad$ Support the U.S. Department of Energy's Building Technologies Office's goals of increasing deployment of energy-efficiency technologies through evaluation of market and cost barriers.

The National Renewable Energy Laboratory, working within the structure of the Clean Energy Manufacturing Analysis Center ${ }^{1}$ and collaborating with researchers at Oak Ridge National Laboratory, analyzed the cost impact and supply of key materials and components in MCR technologies, factors that affect manufacturing location decisions, and quantitative supply chain and market constraints that impact a technology's adoption.

The analysis revealed many important considerations: the most important is that the magnets used in MCR systems will continue to rely on rare earth, neodymium-iron-boron magnets for the foreseeable future. This reliance introduces complex and potentially unpredictable supply constraint issues for the commercialization of MCR systems. These issues are similar to, but potentially more restrictive than, the supply constraints for the magnetocaloric materials themselves because of the particular REEs involved, primarily neodymium but potentially dysprosium as well. The supply landscape of REE shows the predictions for severe shortages for some elements in the next decade. Therefore, substantial effort has been made to map potential for new supply sources, understanding supply changes from current sources and evaluating the potential for recycling of REE to stabilize the supply chain in the future.

Although rare earths could be mined in many places around the world, the highly distributed nature of the reserves and the smaller size of most of individual deposits reduces the economic viability and thus the potential impact they can have on global supply. Furthermore, without a critical mass of production and reserves outside China, it is even more difficult to develop large-

${ }^{1}$ www.jisea.org/manufacturing.html 
scale processing facilities globally, thus further solidifying China's dominance in the REE industry.

The use of neodymium-iron-boron magnets in competing industries was examined, as many of those industries are renewable energy-related industries that are growing rapidly. This fact adds to the demand uncertainty of REE and neodymium-iron-boron magnets and future costs.

Also investigated were research into alternative magnet and electric motor technologies, the intellectual property landscape for rare earths, and REE cost comparisons for vapor compression refrigeration and MCR systems. 


\section{Table of Contents}

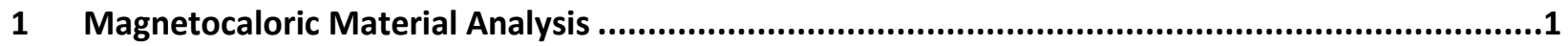

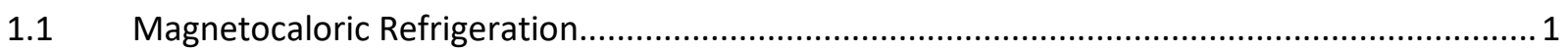

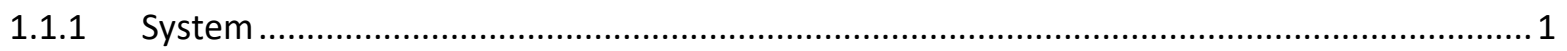

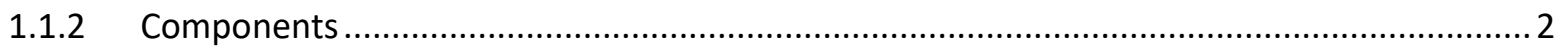

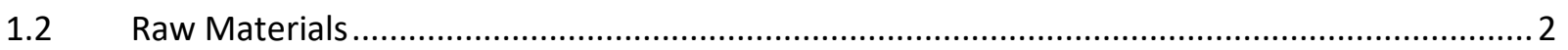

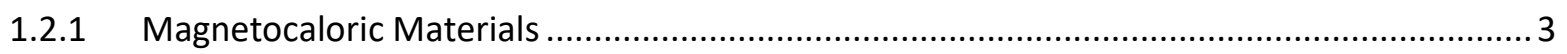

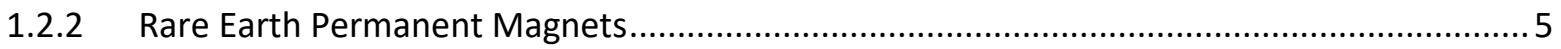

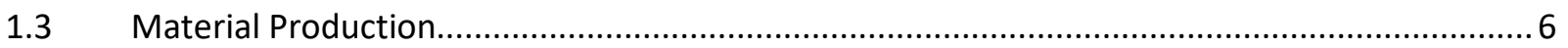

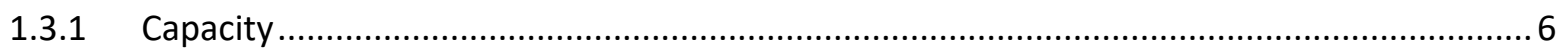

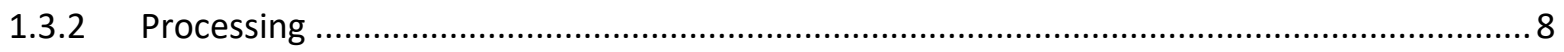

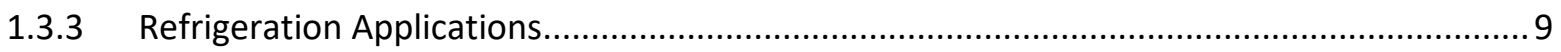

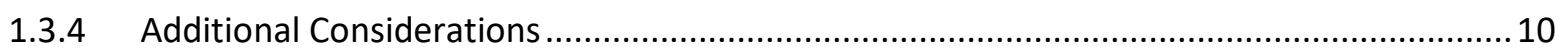

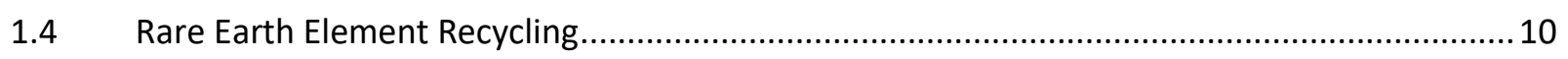

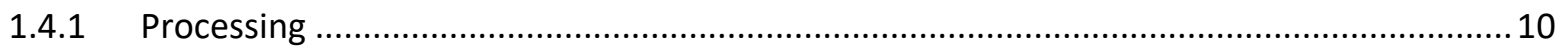

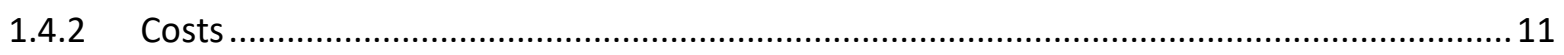

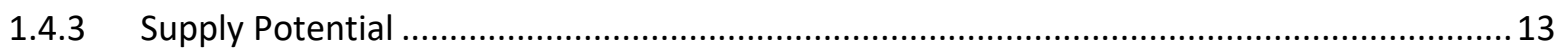

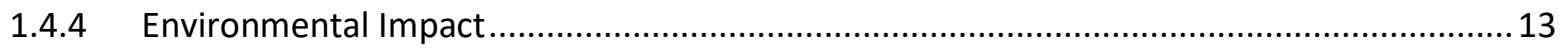

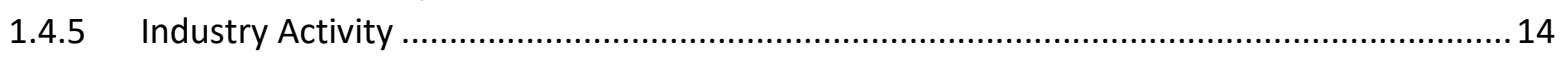

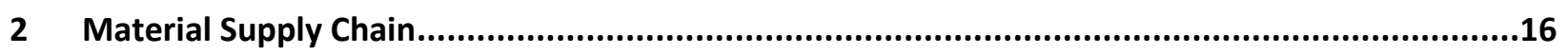

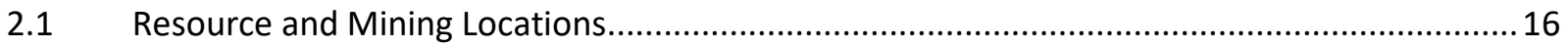

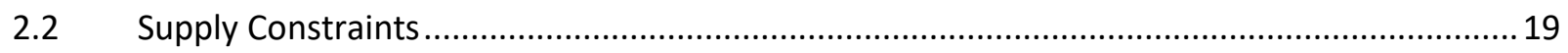

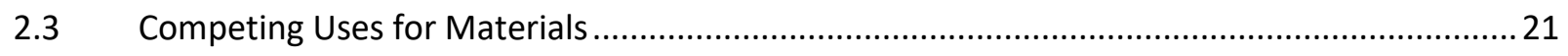

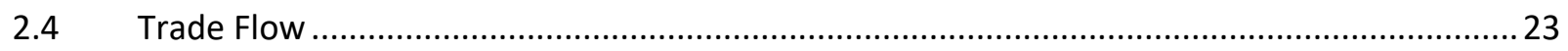

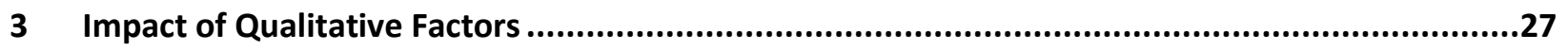

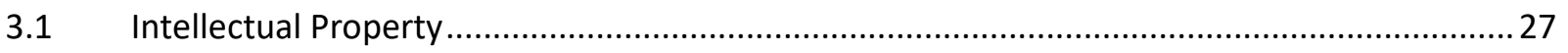

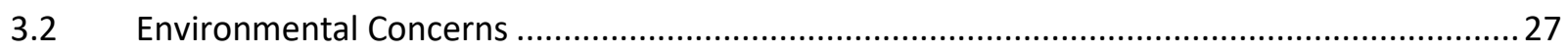

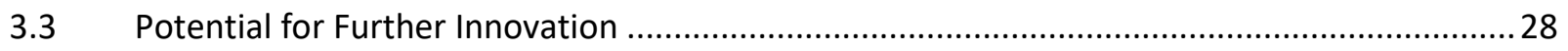

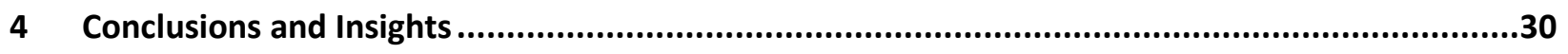

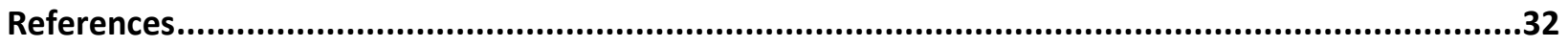

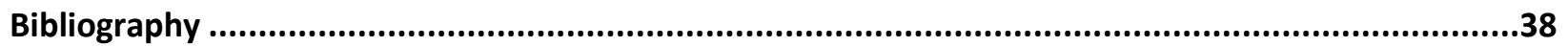

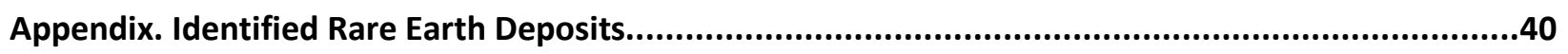




\section{List of Figures}

Figure 1. Magnetocaloric refrigerator system with the magnets engaged with one of the regenerators (left) and with the working fluid reversed and the magnets shifted to engage with the other regenerator (right) ............................................................................... 2

Figure 2. Global annual production and reserves of rare earth elements ............................. 17

Figure 3. Global rare earth ore resources for projects in development as well as identified-but-

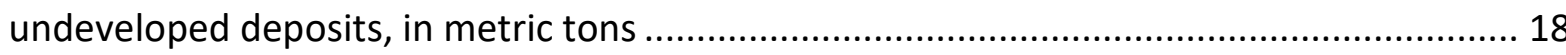

Figure 4. Global rare earth ore resources for projects in development as well as identified-butundeveloped deposits, by percentage concentration of total REO ................................. 19

Figure 5. Historical prices and production for rare earth ore (REO) ..................................... 20

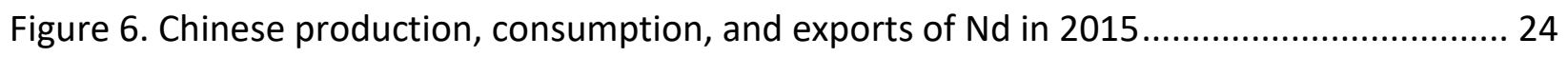

Figure 7. Example of trade flow out of China of cell phones................................................ 25

Figure 8. Re-exports of cell phones for major importing countries from China ....................... 26

\section{List of Tables}

Table 1. Major Components of MCR Systems and Estimated Costs for a System Sized for a Domestic Refrigerator ....................................................................................... 3

Table 2. Estimates When Demand will Exceed Supply for Critical Elements ........................... 6

Table 3. Global Production and Cost of Select REE ......................................................... 7

Table 4. Percentage of Global Domestic Refrigerator Market That Could be Served by Current Global Production of Select REE ....................................................................... 9

Table 5. Approximate Mass of Nd per Device and Cost Required for Recycling to Break Even... 12

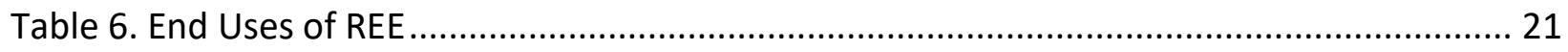

Table 7. Distributions of REO by End Use in the United States ........................................... 22

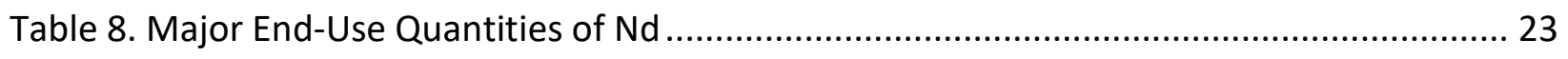

Table 9. U.S. Patents Related to Rare Earth Elements by Expiration Year .............................. 27

Table A-1. Identified Rare Earth Deposits Worldwide ..................................................... 40 


\section{Magnetocaloric Material Analysis}

This section focuses on materials that are critical for magnetocaloric refrigeration (MCR) systems. No room-temperature MCR products are currently available on the market, so some estimation must be made about which components are the most critical. Based on (1) the estimated costs for components and (2) the known or perceived risks in the availability of components or materials, the rare earth permanent magnets (REPM) used to create the magnetic field in the magnetocaloric material and the magnetocaloric material itself are determined to be the components that are most critical to improving performance and enabling commercialization

\subsection{Magnetocaloric Refrigeration}

A detailed review of MCR is beyond the scope of this work; however, many reviews and explanations can be found in the literature. For example, Kitanovski et al. (2015) provide a comprehensive look at the technology as well as its history; only a brief overview is provided here. Magnetocalorics, which have been used for cryogenic refrigeration since the 1930s, became an area of active research for room temperature applications after Pecharsky and Gschneidner (1997) first demonstrated the "giant magnetocaloric effect." 2 The term "giant" is applied because the polarization effect of the newly discovered magnetocaloric materials was $\sim 50 \%$ larger than previously reported.

The general incentives for pursuing MCR are that (1) it has the potential for increased energy efficiency relative to vapor compression systems (Zimm et al. 1998) and (2) it does not use refrigerants that have ozone depletion or global warming potential.

Most system components are commonly available, and they are similar in construction and materials to those currently used in vapor compression systems (e.g., metal heat exchangers and tubing connections). However, differences in other components include the elimination of traditional two-phase refrigerants and the associated compressor, as well as the addition of the magnetocaloric materials and REPMs; a pump and valves for moving the single-phase heat transfer fluid are also included.

\subsubsection{System}

Figure 1 shows a typical schematic for a rotary magnetic refrigeration system with two magnetocaloric regenerators. There are two states that are determined by the position of the magnet relative to the regenerators. The fluid flows are unique to each state. When a regenerator is placed inside the magnet, it heats up. Cold fluid flows simultaneously into the regenerator inside the magnet, removing heat generated from the magnetic field, thus cooling the regenerator. This heated fluid then flows to the hot heat exchanger to be cooled down. The fluid subsequently flows through the cold regenerator outside of the magnet, further cooling the fluid, which then flows to the cold heat exchanger. The magnetic field is applied periodically

2 The larger temperature differences are required for commercial viability of near room-temperature refrigeration. 
to each of the regenerators, with fluid flow changing direction at the same time. The frequency with which the magnet moves between these positions can vary from $\sim 0.2 \mathrm{~Hz}$ to $10 \mathrm{~Hz}$ (Gómez et al. 2013).
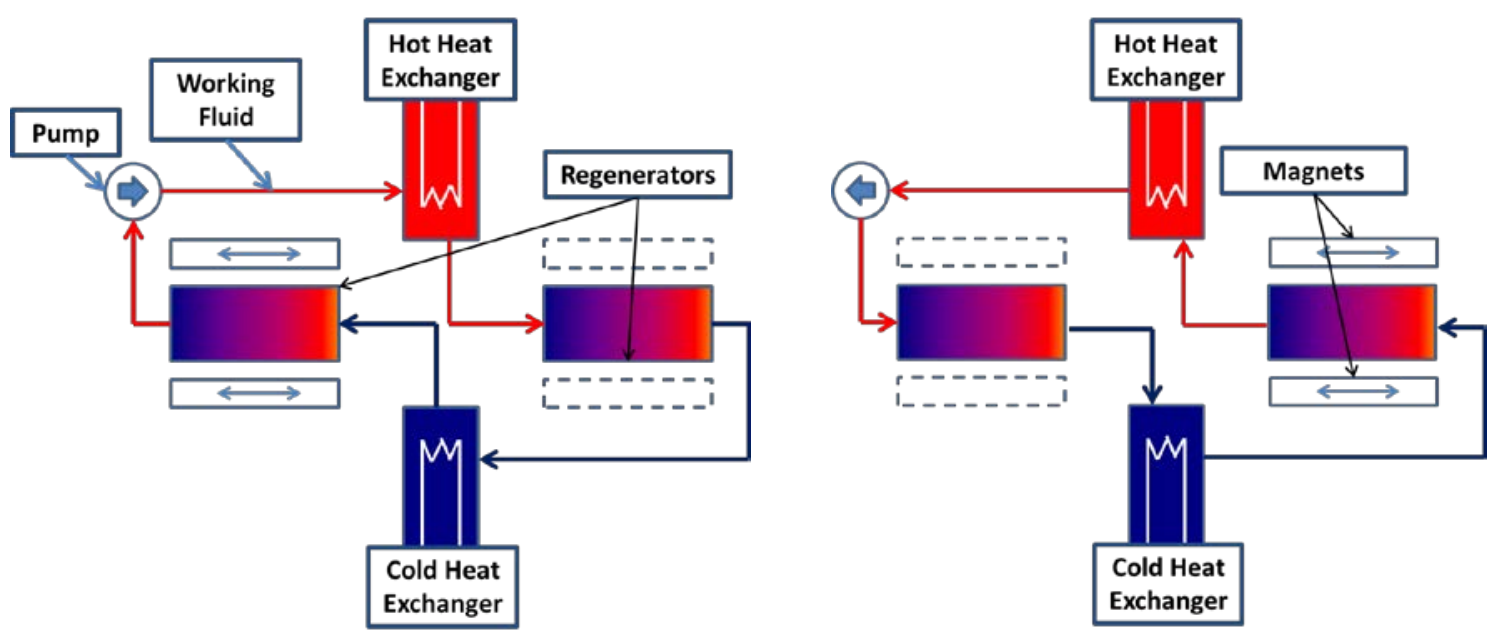

Figure 1. Magnetocaloric refrigerator system with the magnets engaged with one of the regenerators (left) and with the working fluid reversed and the magnets shifted to engage with the other regenerator (right) ${ }^{3}$

\subsubsection{Components}

Table 1 (page 3 ) lists the major system components with their functional descriptions or materials requirements. The approximate costs for most components were estimated via an online search of bulk costs for representative components. Because most of the components are of common materials and construction, an order-of-magnitude estimate on costs is possible; and these estimated costs could guide in-depth research into the most important components

It is readily apparent that the most critical components from a cost perspective are the rare earth-containing magnets and magnetocaloric regenerators; together they account for $~ 75 \%$ of the total component costs. The remainder of the report therefore focuses almost exclusively on providing an in-depth understanding of these components and their respective materials and supply chains.

\subsection{Raw Materials}

The rare earth materials comprising the magnet and the magnetocaloric material are of primary interest because of their cost and availability. Other raw materials are less expensive and easier to obtain with a stable supply chain.

\footnotetext{
${ }^{3}$ All figures and graphics in this report were created at the National Renewable Energy Laboratory by Chuck Booten and Billy Roberts.
} 
Table 1. Major Components of MCR Systems and Estimated Costs for a System Sized for a Domestic Refrigerator

\begin{tabular}{|c|c|c|c|}
\hline Component & Comments & $\begin{array}{l}\text { Estimated Production } \\
\text { Cost per Refrigerator } \\
\text { in High Volume (\$) }\end{array}$ & Primary Materials \\
\hline magnets $^{a}$ & $\begin{array}{l}\text { rare earth permanent magnets } \\
\text { (REPMs) }\end{array}$ & 40 & $\begin{array}{l}\text { neodymium (Nd), Fe } \\
\text { (iron), and boron (B) }\end{array}$ \\
\hline $\begin{array}{l}\text { magnetocaloric } \\
\text { regenerator }\end{array}$ & $\begin{array}{l}\text { sometimes called "solid } \\
\text { refrigerant" because the material } \\
\text { is formed into a heat exchanger } \\
\text { in contact with the heat transfer } \\
\text { fluid; made from gadolinium-, } \\
\text { lanthanum-, or manganese - } \\
\text { based materials }\end{array}$ & 20 & $\begin{array}{l}\text { La-Si-Fe-H } \\
\text { (lanthanum-silicon- } \\
\text { iron-hydrogen) alloy, } \\
\text { Mn-Si-Fe-P } \\
\text { (manganese-silicon- } \\
\text { iron-phosphorus) } \\
\text { alloy, and Gd }\end{array}$ \\
\hline $\begin{array}{l}\text { heat } \\
\text { exchangers }{ }^{b}\end{array}$ & $\begin{array}{l}\text { analogous to the evaporator and } \\
\text { condenser in vapor compression } \\
\text { systems; no phase change } \\
\text { required }\end{array}$ & $\begin{array}{c}3 \\
\text { (for both hot and cold) }\end{array}$ & $\begin{array}{l}\text { Aluminum (Al), Fe, } \\
\text { and copper (Cu) }\end{array}$ \\
\hline $\begin{array}{l}\text { heat transfer } \\
\text { fluid }^{b}\end{array}$ & $\begin{array}{l}\text { replaces traditional two-phase } \\
\text { refrigerants; typically, glycol or } \\
\text { alcohol }\end{array}$ & $<1$ & water and glycol \\
\hline pump ${ }^{b}$ & used to move heat transfer fluid & 3 & $\begin{array}{l}\text { Fe, copper }(\mathrm{Cu}) \text {, and } \\
\text { plastic }\end{array}$ \\
\hline electric motor ${ }^{2}$ & moving magnets & $3-5$ & $\mathrm{Fe}, \mathrm{Cu}$, and plastic \\
\hline yolk ${ }^{b}$ & used to hold magnets in place & 3 & $\mathrm{Fe}$ \\
\hline valve $^{b}$ & $\begin{array}{l}\text { adjusts heat exchanger fluid flow } \\
\text { depending on magnet position }\end{array}$ & $1-3$ & $\mathrm{Fe}$ and $\mathrm{Cu}$ \\
\hline plumbing $^{b}$ & $\begin{array}{l}\text { tubing, connections, and other } \\
\text { parts; operate at much lower } \\
\text { pressure than in vapor } \\
\text { compression systems }\end{array}$ & $1-3$ & $\mathrm{Fe}, \mathrm{Cu}$, and plastic \\
\hline Total & & $75-81$ & \\
\hline
\end{tabular}

a Bjork et al. 2011; M. Benedict, GE Appliances, personal communication, 2016;

unpublished analysis by the National Renewable Energy Laboratory

${ }^{b}$ Prices are wholesale prices for a commercially available component.

\subsubsection{Magnetocaloric Materials}

The magnetocaloric effect is the change in temperature of a ferromagnetic substance that is due to exposure to a magnetic field. When a magnetocaloric substance is exposed to a magnetic field, the entropy decreases because of the alignment of the magnetic moments in the material. In adiabatic conditions, this results in increased temperature. When the magnetic field is removed, the moments become randomized and the temperature decreases. Ferromagnetic materials lose their magnetic properties above a particular temperature called the Curie temperature. This is important because the maximum temperature change due to a magnetic field occurs at the Curie temperature; thus, there must be a close match between the Curie temperature of the material and the operating temperatures of an MCR system for a 
system to be practical. A more thorough explanation is given by Kitanovski et al. (2015). Many magnetocaloric materials have been investigated; the following sections summarize the three most prominent family of materials: gadolinium and gadolinium alloys, lanthanum alloys, and manganese alloys.

\section{Gadolinium}

Gadolinium (Gd), which is the canonical magnetocaloric material, was the first ferromagnetic material discovered with a Curie temperature near room temperature. This characteristic makes it extremely useful for pumping heat near room, such as is done with a refrigeration system. Gadolinium is a heavy rare earth element (REE) that:

Is produced in relatively low quantities: 7,500 metric tons/year (MMTA 2016)

Is typically expensive: $\sim 25 /$ kilogram $(\mathrm{kg})$, which is broadly comparable to the cost of neodymium (Nd) (Statista 2019)

Has a fixed Curie temperature.

Gadolinium is an unlikely candidate for commercialization in a magnetic refrigerator, but it is included here as a well-recognized metric for comparison with newer materials that are in greater abundance and less expensive to produce.

\section{Lanthanum}

Lanthanum (La) is a light REE and is the second most abundant REE after cerium (Bauer et al. 2011). All known deposits of REE contain significant quantities of La. It is typically not a driver of mining activity because of its abundance and relatively low price of $\sim \$ 7 / \mathrm{kg}$ (MineralPrices.com 2016); hence supply depends more on valuable elements that occur within deposits. La is primarily used in clean energy technologies in electric vehicle nickel metal hydride (NiMH) batteries and phosphors for lighting. It is also used in petroleum refining as a catalyst and in solid oxide fuel cells.

Lanthanum is considered a near-critical material by the U.S. Department of Energy (DOE) (Bauer et al. 2011; DOE 2015), and demand is not expected to meet or exceed supply before 2025. Although demand for $L a$ is expected to increase over time, there are many opportunities for substitution (e.g., using Li-ion batteries instead of $\mathrm{NiMH}$ in electric vehicles). Any new REE mines that are developed in the U.S. or abroad would have substantial quantities of La, thus reducing the likelihood of severe supply constraints.

Several manufacturers are developing Lanthanum-based magnetocaloric materials as an alternative to Gd-based alloys. The advantages of Lanthanum-based materials are much higher performance, lower cost, and the ability to adjust the alloy content and thereby adjust the Curie temperature of the material. The ability to adjust the Curie temperature is critical when a large temperature lift is required in the system, as a single Curie temperature makes temperature lifts of more than $25^{\circ} \mathrm{C}$ difficult (Pecharsky and Gschneidner 2007). The alloys typically contain La, iron (Fe), silicon (Si), and hydrogen (H) (Moya et al 2014), but they are difficult to fabricate for many shapes, including microchannels. This can lead to fabrication 
costs that are substantially higher than material costs, thus making the regenerators comparable in cost to magnets in a magnetic refrigeration system. The U.S. Department of Energy is currently sponsoring research activities targeting development of new methods for manufacturing novel shapes from magnetocaloric materials, which would solve this problem (e.g., Momen 2016).

\section{Manganese}

Manganese ( $\mathrm{Mn}$ )-based magnetocaloric materials do not contain any REE, but they are similar to La-based materials in terms of difficulty in fabrication and tunable Curie temperature. Alloys are generally $\mathrm{Mn}$-Fe-P-Si (manganese-iron- phosphorus-silicon) with varying composition to adjust the Curie temperature. A major advantage of these alloys is the greater stability of the supply chain that is due to the lack of REE. Although the constituent materials are inexpensive-Mn is $\sim \$ 1.6 / \mathrm{kg}$ (MineralPrices.com 2016) - the fabrication difficulties can increase the cost of end products by an order of magnitude, similar to La-based materials. However, the work of Momen (2016) has demonstrated the potential to overcome this challenge.

\subsubsection{Rare Earth Permanent Magnets}

The magnets required for practical magnetocaloric heat pumps are either electromagnets or rare earth permanent magnets (REPM). For domestic refrigeration systems, only REPM are practical, as electromagnetic systems are less efficient (Bjork 2011). However, large commercial systems, electromagnets could be a good choice (Evans et al. 2012)

Rare earth permanent magnets are made primarily from $\mathrm{Nd}, \mathrm{Fe}$, and $\mathrm{B}$. Praseodymium ( $\mathrm{Pr}$ ) can be used to partially (up to $\sim 5 \%$ ) offset $\mathrm{Nd}$ (Bauer et al. 2011). Dysprosium (Dy) is a common alloying material that increases the operational temperature of the magnets (Widmer, Martin, and Kimiabeigi 2015). This is important in many applications, with magnets for electric vehicle motors and wind turbines containing $6 \%-12 \%$ Dy by weight (Kramer et al. 2012). However, in lower-temperature applications such as will be encountered in magnetic refrigeration systems, no Dy would likely be needed (M. Benedict, GE Appliances, personal communication, 2016), and a maximum of $0.5 \%$ Dy could be used for supply constraint estimations (S. Constantinides, Arnold Magnetic Technologies, personal communication, 2016). Computer hard disk drives (HDDs), for example, operate near room temperature and typically have less than $1.5 \%$ Dy and often have none (Sprecher et al. 2014; Constantinides 2015).

The global market for REPM is of substantial importance in many industries and is of strategic concern to many countries; therefore, it is a well-studied market, although it is sufficiently complex as to warrant some description here.

China produces $\sim 80 \%-90 \%$ of the global supply of REPM (S. Constantinides, Arnold Magnetic Technologies, personal communication, 2016; Imarc 2016). This is unlikely to change soon, as China holds $\sim 50 \%$ of the world's supply of REE, and it owns most of the processing facilities for both light REE and heavy REE (Humphries 2013). Understanding the importance of the processing facilities is critical, as they represent a major capital investment and are where a 
substantial portion of the pollution and environmental regulations are placed. In some cases, rare earth ore (REO) mined outside China is shipped back to China for processing; this is more common with processing of heavy REE (Golev et al. 2014). Therefore, developing new processing facilities could be as difficult and time-consuming as bringing new REE mines into operation. The closely integrated supply chain within China is a key component in minimizing costs as well. Hitachi recently closed an REPM plant in North Carolina, where costs for magnets were $30 \%-50 \%$ higher than those coming from China (S. Constantinides, Arnold Magnetic Technologies, personal communication, 2016).

Prices of REPM vary based on composition and is mostly related to the dysprosium content. Final prices are approximately twice the price of the constituent materials (S. Constantinides, Arnold Magnetic Technologies, personal communication, 2016); a low/no Dy magnet could be purchased in bulk in 2016 for approximately $\$ 60 / \mathrm{kg}$ (M. Benedict, GE Appliances, personal communication, 2016).

\subsection{Material Production}

Although REPM contain $30 \%-35 \%$ REE by weight, the remainder of the primary constituents, iron and boron, are much less expensive REE are widely produced, and are not considered critical elements (Bauer et al. 2011). The magnetocaloric materials similarly are composed of noncritical materials in addition to rare earths La and $\mathrm{Gd}$. Therefore, material production will focus solely on REE.

Mining and processing are similar for all REE. In addition, they are typically considered together and are largely co-mined, although the relative concentrations of the elements differ by mine. See Section 2 for details.

\subsubsection{Capacity}

DOE's Critical Materials Strategy report (Bauer et al. 2011) provides detailed estimates on global supply and demand for REE and other critical elements including Nd, Dy, and La; estimates of when demand will outstrip supply are shown in Table 2. The DOE study is somewhat dated, given (1) the rapid changes in demand and prices that occur for REE and (2) the rate of commercialization of clean energy technologies that use REPM. The elements cited as critical or near critical remain so today; however, major shortages have not occurred between the publishing of the DOE report (2011) and the present. Nevertheless, even the most optimistic estimates in the report still suggest supply shortages could occur for Nd before 2030, as seen in Table 2.

Table 2. Estimates When Demand Will Exceed Supply for Critical Elements

\begin{tabular}{lcc}
\hline \multirow{2}{*}{ Element } & \multicolumn{2}{c}{ Year } \\
& Min. & Max. \\
\hline Neodymium & 2015 & 2028 \\
Dysprosium & 2010 & 2019 \\
Lanthanum & 2022 & - \\
\hline
\end{tabular}

Adapted from Bauer et al. 2011 
A more recent estimate for Chinese production of REE (Wang et al. 2015) suggests peak production is likely to occur by 2020 , with production in 2050 being $~ 55 \%$ of that level and a wide range of estimates of peak production. Another study (Zhang 2013) estimates peak Nd production in China near 2060 and peak global production between 2077 and 2099. None of these studies includes recycling of REE as a supply resource.

Gadolinium is produced in much lower quantities than Nd or La. It is much less valuable than Dy, with prices similar to those for $\mathrm{Nd}$. There are no current production shortages; however, it is used in several technologies, including solid-oxide fuel cells, nuclear reactors, and medical imaging in addition to MCR. And a substantial increase in demand for these technologies could result in unexpected supply constraints.

Estimates of current global annual production of REE that are potentially important to MCR are given in Table 3 along with recent spot prices and peak prices for reference. Dysprosium is the most critical of these elements because of its scarcity and importance in increasing the high temperature operation range of magnets. Lanthanum is the least critical of these elements despite having much lower production than neodymium because it is not useful in magnet production. Much of the La that is available is not processed completely because of a lack of demand, but it is potentially useful in magnetocaloric materials.

Table 3. Global Production and Cost of Select REE

\begin{tabular}{lccc}
\hline Element & $\begin{array}{l}\text { Approximate Global } \\
\text { Annual Production } \\
\text { (metric tons) }\end{array}$ & $\begin{array}{l}\text { May 2016 Spot } \\
\text { Price (US\$/kg) }\end{array}$ & $\begin{array}{l}\text { Peak Spot } \\
\text { Price (US\$/kg) }\end{array}$ \\
\hline Dysprosium & 870 & 350 & $3,400^{\mathrm{c}}-4,000^{\mathrm{d}}$ \\
Gadolinium & 6,500 & 55 & $150^{\mathrm{f}}$ \\
Lanthanum & 10,600 & 7 & $160^{\mathrm{e}}$ \\
Neodymium & 30,000 & 60 & $450^{\mathrm{b}}$ \\
Zhang 2013; AustralianRareEarths.com 2016; MMTA 2016; SETIS 2016 & \\
pectrum Scientific 2012 & & & \\
Dent 2012 & & & \\
apan Metal Bulletin 2011 & & & \\
IE 2016 & &
\end{tabular}




\section{Magnets: Capacity and Black Market}

Many sources put magnet production at $25 \%-50 \%$ of capacity; however, these estimates are for the processing side and do not account for restrictions and quotas placed on REO production (S. Constantinides, Arnold Magnetic Technologies, personal communication, 2016; S. Trout, Spontaneous Materials, personal communication, 2016; Bloomberg 2014). There are eight licensed manufacturers of rare earth magnets in China; and it is estimated that as many as 250 companies illegally manufacture magnets there as well (S. Constantinides, Arnold Magnetic Technologies, personal communication, 2016, which would mean $\sim 30 \%$ more supply than is tracked via official quotas (S. Constantinides, Arnold Magnetic Technologies, personal communication, 2016). Although this is a high percentage of total production, it is a well-known "secret" with the effects of this production being priced into global markets for REE and derived materials and products. It is therefore implicitly accounted for in many supply and pricing prediction scenarios.

\subsubsection{Processing}

The chemical similarities of rare earths, combined with the co-mining of most elements, mean most of the processing is common to, or very similar for, all elements (De Lima and Filho 2015; Xie et al. 2014).

Three major REO mineral types are currently mined: bastnaesite, monazite and ion-adsorbed clays. The largest REE deposit in the world is the Bayan Obo deposit in China, which contains primarily bastnaesite ore. Ion-adsorbed clays are found in Jiangxi and other Chinese provinces. Details of the mineralogy at major mine sites have been published (De Lima and Filho 2015). Monazite deposits are found in many places (MIT 2016); however, mining of this type of ore is mostly in Brazil, India, Malaysia, South Africa, and Vietnam (King 2016).

Processing of each type of mineral is complex; detailed descriptions of the processes are provided by the U.S. Environmental Protection Agency (EPA 2012), De Lima and Filho (2015), and Sprecher et al. (2014). A brief explanation of the three basic steps (beneficiation, extraction, and reduction) is provided in the following sections.

\section{Beneficiation}

Beneficiation is the physical separation of the REOs from the host material. It involves crushing and grinding of the ore, and it often includes the use of flotation to separate REOs from other materials. The beneficiation step typically results in $60 \%-70 \%$ concentration of REO. Between $25 \%$ and $50 \%$ of REO is not captured during beneficiation and ends up in tailings (De Lima and Filho 2015). This is expected to decrease closer to $25 \%$ with improved technologies (Sprecher et al. 2014).

\section{Extraction}

Extraction is the separation of the REOs from the output of beneficiation via chemical processes that are frequently an environmentally hazardous series of chemical reactions. Hydrometallurgy is the most common method of extraction, although pyrometallurgy and 
electrometallurgy can also be employed. EPA provides a list of various methods along with a brief description of each. At the end of extraction, the REO can be $>99.995 \%$ pure (EPA 2012).

\section{Reduction}

Reduction is the process of turning the oxides into pure metals. The most widely used method is smelting, although alternative methods such as electrolysis are also used. Improvements to this technology offer promise of a more efficient and environmentally friendly method that could allow for United States-based reduction of REOs; development is currently being supported in part by Advanced Research Projects Agency-Energy, or ARPA-E (M. Earlam, Infinium Metals, personal communication, 2016).

\subsubsection{Refrigeration Applications}

Table 4 provides an estimate of the global domestic refrigerator market that could be served with an optimized magnetocaloric heat pump given current production levels. Note that this does not include any future supply changes, such as increased/decreased quotas from China, additional mines that could begin production, or increased supply due to recycling. It also does not account for potential future changes in global domestic refrigerator demand, which is estimated to be 60 million units (Barthel and Götz 2012). Current estimates for optimized magnetic refrigeration heat pumps assumed $\sim 0.8 \mathrm{~kg}$ of REPM and $\sim 0.5 \mathrm{~kg}$ of magnetocaloric material (Bjork 2011; M. Benedict, GE Appliances, personal communication, 2016). The magnet is assumed to have $0.5 \%$ Dy by mass although it is possible an alloy with no Dy could be used given the low-temperature operation (M. Benedict, GE Appliances, personal communication, 2016). The Nd and Dy are assumed to be in the magnet only. The La and Gd are options to be used for the magnetocaloric material; however, only one would be used, not both. The La is the most abundant of the elements listed in the table and thus would use the smallest share of annual production; if $\mathrm{Gd}$ were used, the entire global supply would be consumed while being able to supply only $\sim 25 \%$ of the refrigerator market. This is one reason $\mathrm{Gd}$ is no longer a leading candidate for commercialization of MCR; it is included here mostly as a benchmark, as it is the most recognized and traditional magnetocaloric materials.

Regardless of which materials would be used, Table 4 makes it clear that if all refrigerators used MC technology it would significantly strain the supply of these materials.

Table 4. Percentage of Global Domestic Refrigerator Market That Could be Served by Current Global Production of Select REE

\begin{tabular}{lcc}
\hline Element & $\begin{array}{c}\text { Global Refrigerator } \\
\text { Market Served (\%) }\end{array}$ & $\begin{array}{c}\text { Global Annual } \\
\text { Production (\%) }\end{array}$ \\
\hline neodymium & 10 & 5 \\
dysprosium & 10 & 2 \\
lanthanum & 10 & 2 \\
gadolinium & 10 & 40 \\
manganese & 10 & 0 \\
\hline
\end{tabular}




\subsubsection{Additional Considerations}

Smith Stegen (2015) provides a practical overview of the rare earths industry, including production, processing and supply chain issues. Not only does China dominate the mining/production of REE, but almost all processing is done there. This is particularly true for heavy REE, as no facility outside of China currently processes them. So, even if resources are mined in other countries, they must be transported to China for processing and value addition. Only one facility (Rhodia's La Rochelle plant in France) could be used to process heavy REE, but there are no plans to do so, and even if they were processed there, the capacity would be limited.

\subsection{Rare Earth Element Recycling}

Currently, less than $1 \%$ of REE are recycled (EPA 2012). This is largely because of the difficulty and cost associated with recycling as those products typically contain small and often dispersed amounts of REE and they frequently require users to pay to recycle items that contain them.

Given the variability in the feedstock for recycling, it is worth estimating where the greatest value can be found. The focus in this report is on $\mathrm{Nd}$ (which serves as a proxy for Dy as well), although some information is provided on La. There are several reasons for this:

The values of La and $\mathrm{Mn}$ are lower than those of $\mathrm{Nd}$ and $\mathrm{Dy}$.

Gadolinium is presented here generally as a benchmark; it is unlikely to play a significant role in magnetocaloric heat pump commercialization. It is used in very small quantities in most applications (i.e., 0.3\% in lighting phosphors, according to Bauer et al. [2011]), and recycled $\mathrm{Gd}$ is likely to be radioactive after use in nuclear reactors.

La, Gd, and Mn are less critical than Nd and Dy (Bauer et al. 2011).

\subsubsection{Processing}

Recycling is a multistep process that initially can be very different depending on the feedstock. EPA provides a thorough description of the steps which are summarized here (EPA 2012).

Collection consists of (1) gathering of rare earths material during production or processing (preconsumer) and (2) gathering end-of-life products, such as consumer electronics and electric motors (post-consumer).

Pre-consumer: $20 \%-30 \%$ of magnet material is lost during processing and fabrication (EPA 2012; Sprecher et al. 2014; S. Constantinides, Arnold Magnetic Technologies, personal communication, 2016). Steel mill slag contains $\sim 0.032 \% \mathrm{Nd}$ by weight (Bandara et al. 2015).

Post-consumer: This step involves consumer electronics such as HDDs, speakers/headphones, cell phones (vibrators and speakers), cordless power tools, EV drive motors, electric bicycles, wind turbine generators, $\mathrm{A} / \mathrm{C}$ compressors, and raw magnets.

Dismantling is primarily targeted at post-consumer products. REE are typically used in magnets and batteries, which are complicated in themselves, but which also can be embedded in more 
complex products. Inefficient dismantling frequently damages REPM and can result in up to $90 \%$ loss in HDDs (Sprecher et al. 2014).

Separation is primarily targeted at post-consumer products. This is an important step because most products use small quantities of REE; thus, separation can be a time-consuming process that results in small amounts of rare earths material being recovered. For example, every 700 $\mathrm{kg}$ of electronics scrap contains an average of one HDD (Sprecher et al. 2014) with 12-14 grams of REPM (Hatch 2011).

Processing is a necessary step for almost all rate earths recycling, pre or post-consumer, unless the material will be reused in its previous form, which is unlikely. The three basic categories of processing are listed below; details are given by Firdaus (2016).

Hydrometallurgical

Most common approach

Most similar to processing of raw material

Large amounts of chemicals and water

Many steps and lots of energy

Pyrometallurgical

Used for alloy recycling

Roughly corresponds to extraction part of raw material process

Materials regenerated into a master alloy

Good when water is scarce/valuable and waste needs to be limited

Mechanical/Physical

Recovering magnets whole and reusing; this is not typical for magnets and even less so for battery recycling.

\subsubsection{Costs}

The primary industry focus on recycling appears to be intended to guard against future supply constraints and resulting price instability (Minter 2010; Kenji, Hiroshige, and Nemoto 2013). And Hitachi has explicitly stated that their goal "is to guard against fluctuations in the price of rare-earth magnets" (Kenji, Hiroshige, and Nemoto 2013).

Little information about costs is available, with the implication being that recycling is currently not as cost-effective as using newly mined/processed materials. Also, much if not most, of the activity in this area is at the research or pilot stage; thus, high-volume costs are unknown. EPA (2012) has compiled a list of several organizations that are developing REE recycling processes.

Table 5 shows the most common products in which $\mathrm{Nd}$ is currently used. The focus of the table is on (1) Nd rather than Dy, which might or might not be present in some of the devices and (2) 
magnetocaloric materials such as La or Mn, as they are not subject to as severe of supply constraints. Gd has few commercial uses and is therefore not considered. The table is intended to illustrate the value and the difficulties of recycling $\mathrm{Nd}$ over the majority of the markets where it is used.

Table 5. Approximate Mass of Nd per Device and Cost Required for Recycling to Break Even

\begin{tabular}{|c|c|c|c|}
\hline Device & Mass Nd & $\begin{array}{l}\text { Market Value } \\
\text { of Nd per } \\
\text { Device }\end{array}$ & $\begin{array}{l}\text { Allowable Time for Recycling to Break } \\
\text { Even with New Material Costs }\end{array}$ \\
\hline $\mathrm{HDD}^{\mathrm{b}}$ & $4 \mathrm{~g}$ & 0.24 US\$ & 2.9 mins. \\
\hline cell phone ${ }^{c}$ & $0.3 \mathrm{~g}$ & 0.02 US\$ & 0.23 mins. \\
\hline $\begin{array}{l}\text { A/C } \\
\text { compressor }^{d}\end{array}$ & $30 \mathrm{~g}$ & 1.80 US\$ & 18 mins. \\
\hline electric vehicle & $500 \mathrm{~g}$ & 30 US\$ & 360 mins. \\
\hline wind turbine & $165 \mathrm{~kg} / \mathrm{MW}$ & $\begin{array}{r}9,900 \\
\text { US\$/MW }\end{array}$ & 1,980 hours/MW \\
\hline
\end{tabular}

\footnotetext{
a Assumes $\$ 5 / \mathrm{hr}$ labor cost

${ }^{\mathrm{b}}$ Hatch 2011

c Zepf 2013

d Clenfield, Yasu, and Biggs 2010
}

Break-even time does not account for additional costs associated with reprocessing of $\mathrm{Nd}$, which can be significant but depend heavily on the state of the recycled $\mathrm{Nd}$ and intended purpose for the reprocessed material (De Lima and Filho 2015).

Consumer electronics such as cell phones and HDDs are often touted as prime targets for recycling because of their high sales volume; almost 700 million HDDs were sold in 2010 (Zepf 2013), and 1.4 billion smartphones are sold per year (Statista 2016). However, the very small amount of $\mathrm{Nd}$ in a single device makes dismantling and separating the magnets difficult. Cell phones, in particular, require a very efficient process, as the $0.3 \mathrm{~g}$ of $\mathrm{Nd}$ is distributed in the vibration mechanism, speaker, and headset (Zepf 2013). Break-even costs at 2016 prices would require that recovering all the $\mathrm{Nd}$ in a phone take less than 14 seconds as shown in Table 5.

HDDs can be recycled at a reasonable cost, with some estimates suggesting manual teardown takes as little as two minutes (Scrap Metal Forum 2016). However, because HDDs contain information, they must also be completely destroyed, typically by shredding. If the magnets are not removed first, $\sim 90 \%$ of the magnet material is lost (Sprecher et al. 2014). If all the magnetic material could be recovered and the associated reprocessing costs of the materials are considered, recycling HDDs could be cost-competitive with purchasing new material. Hitachi has developed a method for separating and extracting REPM from HDDs and air conditioning compressors that reduces the time by as much as $8 x$ (Hitachi 2010), to near 40 seconds per HDD.

Mitsubishi has developed equipment that can dismantle an air conditioning compressor in 30 seconds (Mitsubishi 2014), which is well below the break-even cost relative to purchasing new materials. However, motor recycling can be more challenging. A study focusing on electric 
vehicles found that magnet damage was common during disassembly because (1) of brittleness during mechanical removal and (2) many of the adhesives used during assembly melt at a lower temperature than that of the demagnetization process, leading to uncontrolled magnet movement during disassembly (Li 2016).

\subsubsection{Supply Potential}

Global annual use of $\mathrm{Nd}$ for key devices was given in Table 5, but those uses account for only $\sim 40 \%$ of total global demand. The other major end uses are electric motors (i.e., power tools, industrial motors, and generators), CD/DVD players, transducers and loudspeakers, and magnetic resonance imaging machines (Imarc 2016).

Humphries (2013) provides REE uses by industry for the United States and world demand but does not differentiate by individual element. Humphries (2013) also shows major uses of REE as catalysts (La is commonly used) and for polishing (Cerium [Ce] is commonly used) as well as phosphors (La, Ce as well as europium, terbium, and yttrium).

In terms of practical potential for recycling Nd supply, estimates vary widely from less than $10 \%$ (Rademaker 2013) to $20 \%$ for the most critical REE (Schulze and Buchert 2016) and up to $40 \%$ overall (De Lima and Filho 2015) by 2030. Xu, Yano, and Sakai (2016) estimate that recycling of electric vehicle batteries and motors could supply 23\% (31 tons) of Dy and 49\% (520 tons) of Nd for the domestic demand in Japan by 2030. Cerium and La obtained from NiMH batteries account for the bulk of the recycled material: more than 1,200 and 803 tons/yr respectively. And the overall recovery efficiency is estimated to be $81 \% \pm 14 \%$ (Xu, Yano, and Sakai 2016).

Slag from steel mills has also been considered as a source of REE, primarily Nd (Bandara et al. 2015), as have mine tailings, red mud from bauxite processing, and wastewater streams (Binnemans et al. 2013), although reliable estimates for the yearly production potential are unavailable.

\subsubsection{Environmental Impact}

The relative environmental impacts of recycling for REE and mining for them strongly depends on the recycling processes used. And these processes depend heavily on the recovery methods, the original use versus the intended use of the recycled product, and local environmental regulations.

Sprecher et al. (2014) performed a simulation study of life cycle costs for Nd magnets from HDDs given three different production scenarios: a high, a medium, (baseline), and a low technology production/process approach. In addition, two recycling scenarios were considered: shredding and manually separating HDDs. The simulation included detailed treatment of all major processing and recycling steps. Sprecher et al. (2014) concluded recycling represents a major improvement over mining from an environmental point of view (i.e., considering energy use and human toxicity); toxicity is primarily in the form of hydrogen fluoride which is used in acid roasting during extraction. The choice of recycling method (i.e., shredding versus manually separating HDDs) also has a major influence on the impact, given the difference in associated REE recovery rates. 
Reduction in other toxic chemicals, such as tetrafluoromethane $\left(\mathrm{CF}_{4}\right)$, is a major selling point for Infinium, a startup company funded in part by ARPA-E that specializes in electrowinning (M. Earlam, Infinium Metals, personal communication, 2016). Infinium's process does not form $\mathrm{CF}_{4}$, thereby dramatically reducing some of the toxic byproducts of REE and other metal processing/recycling such as that used for magnesium. Their process also provides a possible method for locating certain types of processing in industrialized countries, such as the United States, where many end-use products can be recycled.

\subsubsection{Industry Activity}

Many companies are either developing recycling processes for REE or have already begun commercial recycling of REE. Interests are generally along two lines: (1) fluorescent lighting recycling and (2) electric vehicle batteries and magnet recycling.

Solvay is a Belgian company that, among other pursuits, recycles fluorescent lights. The feedstock is readily available, as recycling of fluorescent bulbs is mandatory in Europe (Free 2014). Solvay has recycled more than 1,000 tons of bulbs thus far, and it sells the recycled fluorescent precursor to lamp manufacturers (Free 2014). Phosphors in these lights typically contain La, Ce, Europium (Eu), tellurium (Te), and yttrium (Y).

Electric vehicle batteries typically contain $\mathrm{La}, \mathrm{Ce}, \mathrm{Li}$, cobalt (Co), Mn, and nickel (Ni). Battery chemistries are typically $\mathrm{NiMH}$ or Li-ion. Li-ion batteries use lithium nickel manganese cobalt oxide, while $\mathrm{NiMH}$ can use $\mathrm{La}, \mathrm{Ce}, \mathrm{Pr}$, and nickel manganese cobalt oxide. Honda and Japan Metals \& Chemicals have recycled NiMH electric vehicle batteries at an estimated recovery rate of $80 \%$ using molten salt electrolysis (Clancy 2014); the recovered anode materials are intended to be included in new EV batteries. And Standridge and Corneal (2014) suggests $85 \%$ of Li-ion batteries could be recycled, with cost parity compared to new batteries at a lithium (Li) price of $\sim \$ 100 / \mathrm{kg}$.

Umicore is a materials technology company that specializes in nonferrous precious metal recycling, including recycling of consumer electronics, catalysts, and $\mathrm{NiMH}$ batteries. It works with Rhodia (which is owned by Solvay) to separate Ni and Fe from rare earths in batteries (Umicore) and refine the rare earths (Rhodia) (Reisch 2011).

Other major recycling targets involve REPMs, the most common being those in electric motors (e.g., electric cars and bicycles, air conditioner compressors, and wind turbines) and consumer electronics (e.g., HDDs and cell phones).

Many companies are also developing technologies for magnet recycling. EPA (2012) compiled a list of commercial and pre-commercial REE recycling activities; although the list is somewhat dated, it provides a starting point for understanding activity in the area. Hitachi has developed technology for recycling HDDs and air conditioning compressors, and it is in the process of commercialization; for air conditioners, the time is approximately eight minutes per compressor and for HDD, the process is approximately eight times faster than manual separation (Clenfield, Yasu, and Biggs 2010). 
DOE and Oak Ridge National Laboratory recently licensed an REPM recycling process to Momentum Technologies that focuses on automating the recovery process and sorting and aligning magnets from HDDs (ORNL 2016).

Infinium recently announced a partnership with DOE's Critical Materials Institute to demonstrate production of rare-earth magnets sourced and manufactured in the United States. Such domestic production would necessarily require that rare earths be recycled, but there is currently no domestic rare earth mining (Ames Laboratory 2016a).

Fraunhofer has developed a melt spinning process for recycling magnet material where the crystal structure can be varied in the recycled material (Fraunhofer 2015). 


\section{Material Supply Chain}

That the REE supply chain is very heavily concentrated in China-including mining, processing and incorporating finished materials into final products, which are then frequently exportedcreates a challenging environment for diversifying the supply chain.

In addition to being heavily concentrated geographically, the supply chain for REE is also largely linear. It begins with mining and then proceeds to processing (including separation of the different elements); only after that is there diversification, with metals and/or compounds moving to different industries depending on end uses. However, even then, much of the incorporation into products (e.g., magnets or fluorescent lighting) and the subsequent incorporation of those components into final products (e.g., electric motors or HDDs) occurs within China. Such a situation makes tracking of materials and trade flows difficult.

There is some diversification in production and processing based on the category of REE. Heavy REE are almost exclusively mined and processed in China. The more common, and less valuable, light REE have some production and processing in various countries.

\subsection{Resource and Mining Locations}

Although REEs are fairly common in Earth's crust, they exist in sufficient concentrations in so few locations that they cannot be mined economically. Figure 2 (page 17) shows a map of annual production and reserves by country. China clearly dominates production with $85 \%$ of the global total (USGS 2016; S. Constantinides, Arnold Magnetic Technologies, personal communication, 2016). Some estimates put the total closer to 97\% (POST 2011). Note that this does not differentiate between light and heavy REE production, nor does it provide insight on where the processing of REO occurs. Stegen (2015) notes that all heavy REE processing as well as most light REE processing occurs in China; therefore, even ore that is mined in other countries is frequently shipped to China.

Also note that due to changes in United States Geological Survey (USGS) rules, the reported U.S. reserves in 2016 were almost an order of magnitude lower than previous USGS estimates and estimates from many other sources. This is because USGS decided to include only reserves that are compliant with recognized standards (USGS 2016). Other sources provide more detail about mines that are in various stages of development, but which are not yet in production (AustralianRareEarths.com 2016), including location by country, reserves, REO concentration, and relative concentration of different elements; details are provided in the appendix.

Figure 2 also shows global reserves, which are much more evenly distributed than production. The greater distribution of reserves over current production is potentially advantageous for diversifying the supply chain; however, REO processing is environmentally damaging and, in combination with the dominance of China in this area, it is difficult to envision a near-or medium-term path in which China does not exert major influence on the global supply of REE. 
Brazil is actively developing several REE mines with various geological characteristics, but current production is small at 100 metric tons/month (De Lima and Filho 2015). Some estimates have $\mathrm{Nd}$ reserves alone at more than 28 million metric tons (Miningtechnology.com 2016).

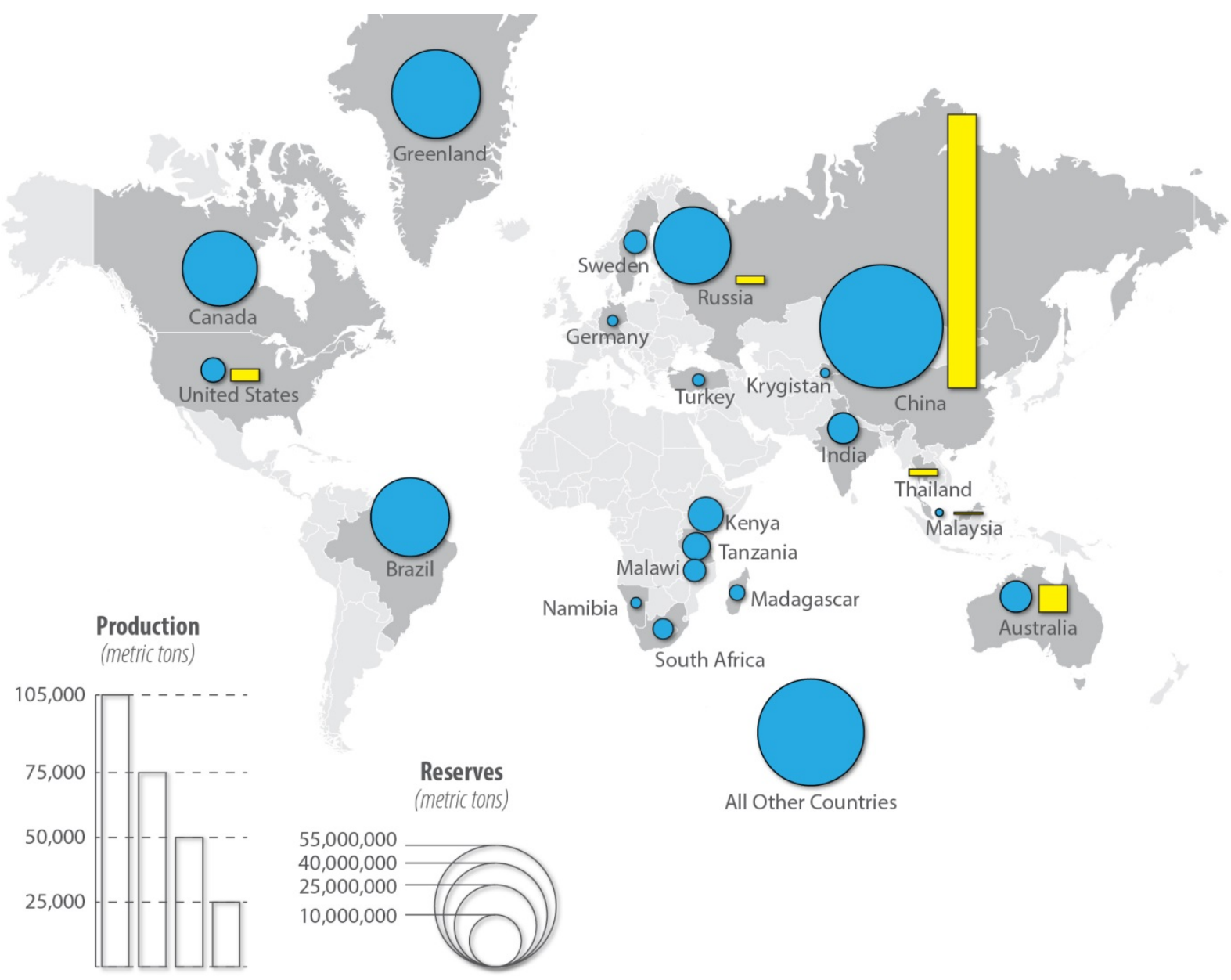

Figure 2. Global annual production and reserves of rare earth elements

Other countries include Greenland, which has a very large deposit that includes substantial heavy REO (USGS 2016; Technology Metals Research 2015).

Figure 3 and Figure 4 provide country-level detail on some of the larger REO resources presented in Figure 2. Both figures break down the resource into heavy rare earth ore and light rare earth ore, which is a convenient and logical split because the price, and therefore commercial viability, of mining a resource depends largely on such as split. The elements in heavy rare earth ore tend to have similarly high values, and the elements in light rare earth ore have similarly low values. The exception to this is $\mathrm{Nd}$, which is a light $\mathrm{REE}$, but which commands a higher price. 


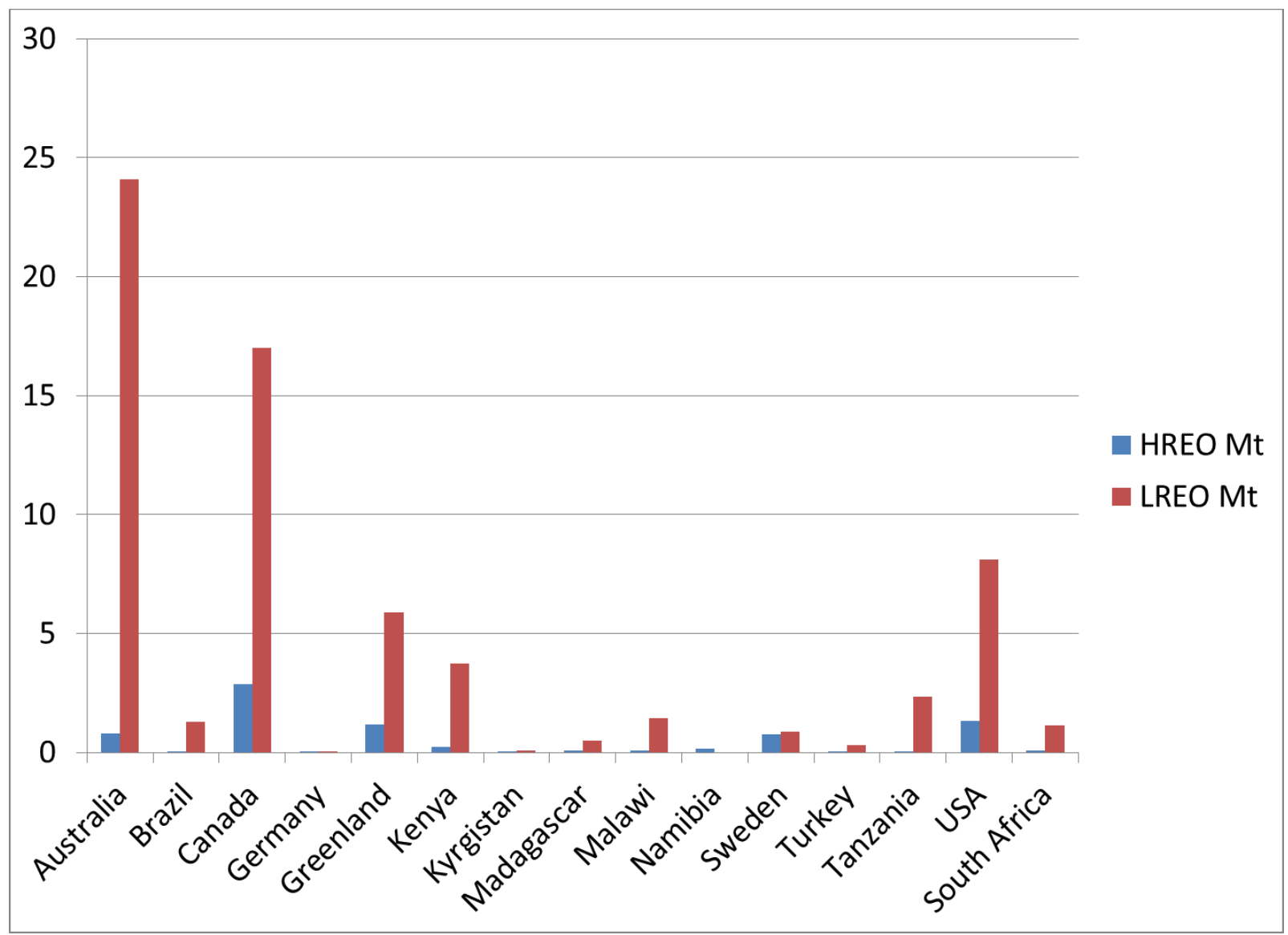

Figure 3. Global rare earth ore resources for projects in development as well as identified-butundeveloped deposits, in metric tons

The resources are split by heavy (HREO) and light (LREO) elements (Technology Metals Research 2015).

These figures illustrate that although REE could be mined many places in the world, the highly distributed nature of the reserves and the small size of most of the individual deposits further solidify China's dominance in the REE industry. Furthermore, without a critical mass of production and reserves outside China, developing large-scale processing facilities outside China is even more difficult. 


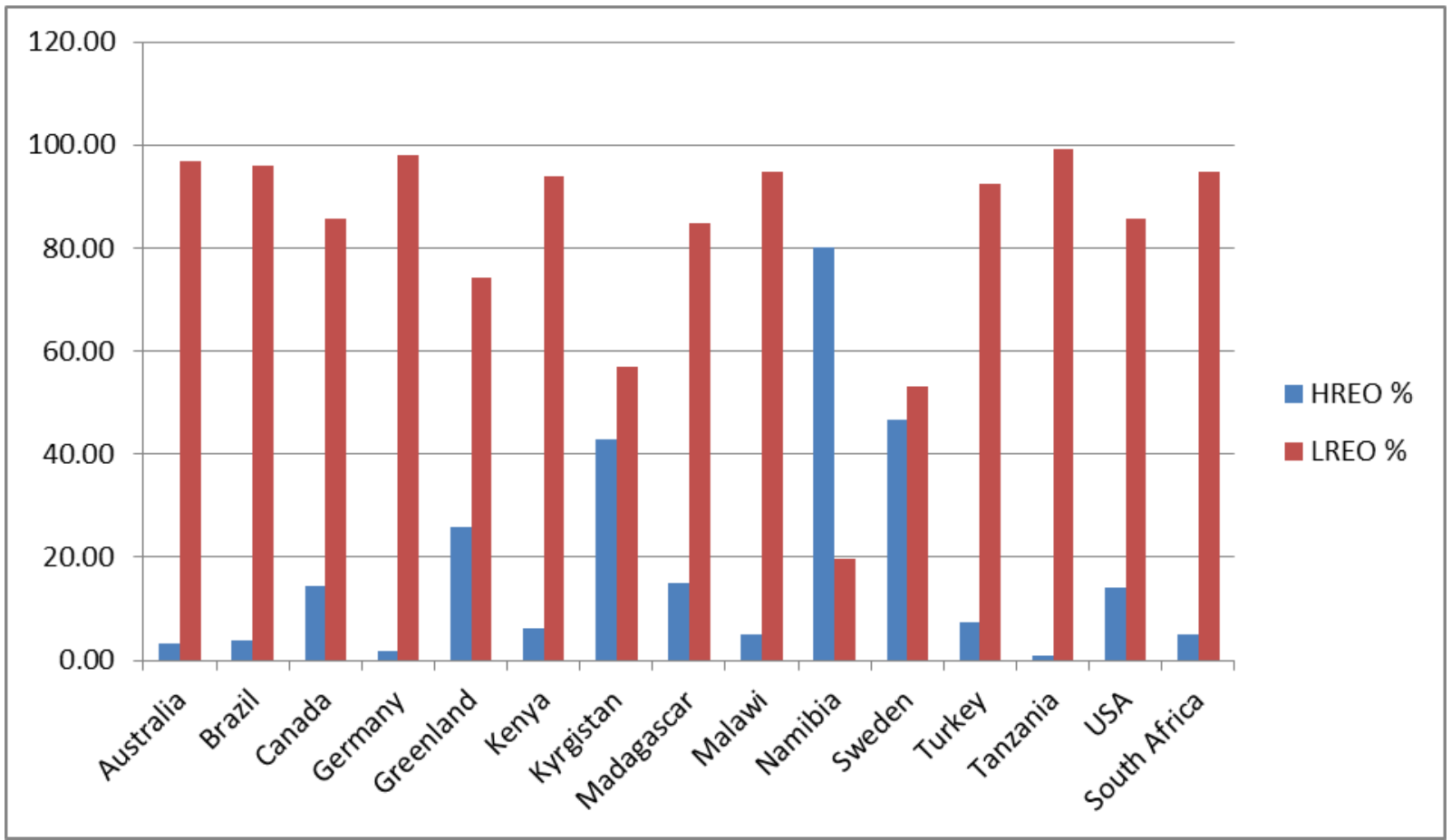

Figure 4. Global rare earth ore resources for projects in development as well as identified-butundeveloped deposits, by percentage concentration of total REO

The resources are split by the percentage of heavy (HREO, or heavy rare earth ore) versus light (LREO) elements (Technology Metals Research 2015). Some smaller deposits such as those in Kyrgyzstan, Namibia, and Sweden could be commercially attractive even though given the higher concentration of the much more valuable heavy rare earth ore in those deposits.

\subsection{Supply Constraints}

The rare earth industry experienced substantial upheaval starting in 2011. Before then, prices were relatively stable.

Figure 5 shows historical prices for REO; prices shown as zero are unavailable. It can be seen that by far the most dramatic price fluctuations happened in 2011, when China imposed its well-documented export restrictions. Prices have since recovered to closer to historical norms; however, that price spike motivated many organizations to explore ways to diversify supply, including by spurring recycling efforts. Ironically, the recovery from the peak prices has also prevented many mining companies and investors from undertaking the development of new mines. Developing a new rare earth mine can take well over a decade and require large capital expenditures, as developers face uncertain and potentially shifting regulatory and environment requirements (EPA 2012). The restarting of the Mountain Pass mine in California during the price spike and the subsequent bankruptcy of Molycorp after prices recovered highlights the investment risks involved in rare earth mine development. 


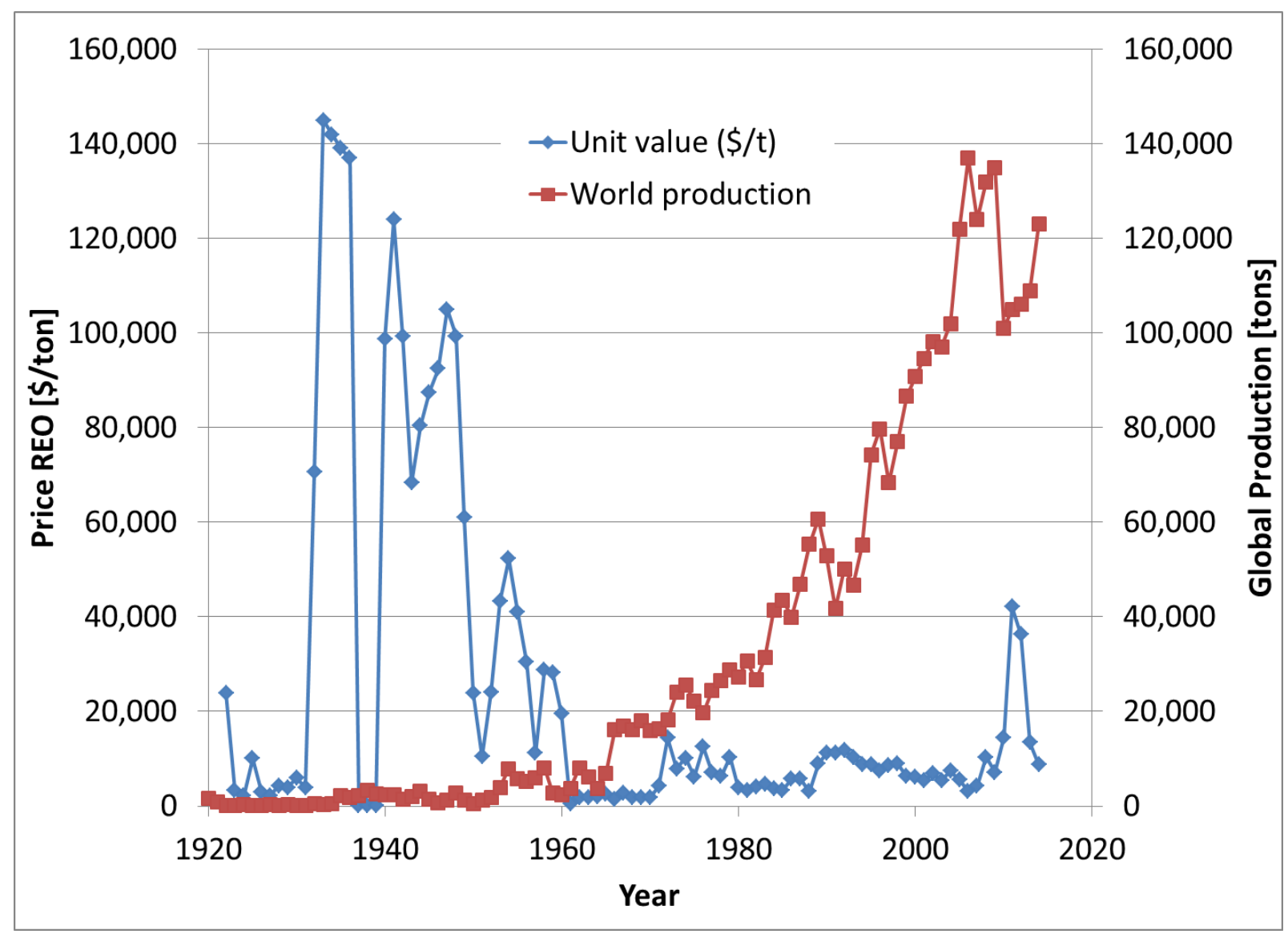

Figure 5. Historical prices and production for rare earth ore (REO)

The REO content is based on averages contained in United States-mined ore from bastnaesite and monazite. General stability has persisted over the second half of the $20^{\text {th }}$ century and until 2011 (DiFrancesco 2016). Prices are adjusted to 1998 dollars.

However, even with the challenges facing new mine development, new mines are beginning production, notably in Australia. And exploration efforts continue in the United States, Australia, Madagascar, Brazil, Russia, Greenland, India, and other countries (USGS 2016). It should be noted that many or most of these deposits are smaller than Chinese deposits and production, or they consist primarily of the less valuable light REE; see the appendix for mineral compositions at various mines and potential mine sites.

EPA (2012) provides a detailed graph of 114 known U.S. REO deposit locations and a corresponding description of the deposits. Most of these are small, low-concentration occurrences of REO with unproven reserves, and they are not being actively developed. As noted in Section 1.3.4, even if these deposits were developed into operating mines, which would take many years and could be financially perilous, processing the ore into useful materials would still be a major obstacle to diversifying the supply chain and reducing supply risk. 


\subsection{Competing Uses for Materials}

Table 6 shows where REE that are relevant to MCR are used. Neodymium and Dy are used in the same areas, as they are almost exclusively used in permanent magnets. Clean energy technology applications are listed first, followed by other applications. The percentage usage for $\mathrm{Nd}$ and Dy are approximately equal and are detailed many places (DeLima and Filho 2015; Imarc 2016). DOE provides estimates for clean energy versus other energy uses for all elements except gadolinium for 2025 (Bauer et al. 2011).

Table 6. End Uses of REE

\begin{tabular}{|c|c|c|c|c|c|c|}
\hline & & & & & \\
\hline & & Lanthanum & Neodymium & Dysprosium & Gadolinium & Manganese \\
\hline \multirow{6}{*}{ 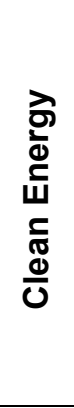 } & wind turbines & & $x$ & $x$ & & \\
\hline & EVs: NiMH & $x$ & $x$ & $x$ & & $x$ \\
\hline & EVs: Li lon & & $x$ & $x$ & & $x$ \\
\hline & $\begin{array}{l}\text { fluorescent } \\
\text { lighting }\end{array}$ & $x$ & & & $x$ & \\
\hline & fuel cells & $x$ & & & $x$ & \\
\hline & electric bicycles & & $x$ & $x$ & & \\
\hline \multirow{8}{*}{ 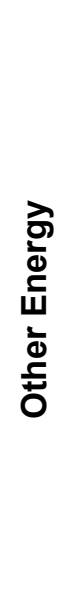 } & HDDs & & $x$ & $x$ & & \\
\hline & speakers & & $x$ & $X$ & & \\
\hline & $\begin{array}{l}\text { magnetic } \\
\text { resonance } \\
\text { imaging } \\
\text { machines }\end{array}$ & & $x$ & $x$ & $x$ & \\
\hline & A/C compressors & & $x$ & $x$ & & \\
\hline & steel production & & & & & $x$ \\
\hline & catalysts & $x$ & & & & \\
\hline & optics & $x$ & & & & \\
\hline & nuclear reactors & & & & $x$ & \\
\hline
\end{tabular}

Sources: DOE 2015; Imarc 2016.

Manganese is included because it is an important metal that could be used as the basis for a magnetocaloric material.

$\mathrm{EV}=$ electric vehicle

U.S. end uses of REE are summarized in Table 7. Nd, Pr, Dy, and La are the most relevant elements for magnetocalorics. Praseodymium, which is not considered critical, is generally used in small quantities as a substitute for $\mathrm{Nd}$ in magnets (Bauer et al. 2011), and it is therefore not been in detail here. Lanthanum is also not a critical element; however, it could be important as a major component in magnetocaloric materials that are being developed. Neodymium is used in several applications, but magnets are by far the dominant use of $\mathrm{Nd}$. 
Table 7. Distributions of REO by End Use in the United States

\begin{tabular}{|c|c|c|c|c|c|c|c|c|c|c|c|}
\hline \multirow[b]{2}{*}{ End Use } & \multicolumn{11}{|c|}{ Quantity REO in Kilotons } \\
\hline & $\begin{array}{l}\mathrm{CeO} \\
2\end{array}$ & $\begin{array}{l}\mathrm{La}_{2} \mathrm{O} \\
3\end{array}$ & $\begin{array}{l}\mathrm{Nd}_{2} \mathrm{O} \\
3\end{array}$ & $\begin{array}{l}\mathrm{Y}_{2} \mathrm{O} \\
3\end{array}$ & $\begin{array}{l}\operatorname{Pr}_{6} \mathrm{O}_{1} \\
1\end{array}$ & $\begin{array}{l}\mathrm{Dy}_{2} \mathrm{O} \\
3\end{array}$ & ${ }_{3}^{\mathrm{Gd}_{2} \mathrm{O}}$ & $\begin{array}{l}\text { Sm } \\
0\end{array}$ & $\begin{array}{l}\mathrm{Tb}_{6} \mathrm{O} \\
7\end{array}$ & $\begin{array}{l}\mathrm{Eu}_{2} \mathrm{O} \\
3\end{array}$ & $\begin{array}{l}\text { Othe } \\
r\end{array}$ \\
\hline $\begin{array}{l}\text { Automobil } \\
\text { e catalytic } \\
\text { converters }\end{array}$ & 6.80 & 0.38 & 0.23 & 一 & 0.15 & - & - & - & - & - & - \\
\hline Ceramics & 0.84 & 1.20 & 0.84 & 3.71 & 0.42 & & & & & & \\
\hline $\begin{array}{l}\text { Fluid } \\
\text { catalytic } \\
\text { cracking }\end{array}$ & 1.98 & 17.80 & - & - & - & - & - & - & - & - & - \\
\hline $\begin{array}{l}\text { Glass } \\
\text { additives }\end{array}$ & 7.90 & 2.90 & 0.36 & 0.24 & 0.12 & - & - & - & - & - & 0.48 \\
\hline $\begin{array}{l}\text { Metallurgy } \\
\text {, except } \\
\text { batteries }\end{array}$ & 5.98 & 2.99 & 1.90 & 一 & 0.63 & - & - & - & - & - & - \\
\hline $\begin{array}{l}\mathrm{Nd} \\
\text { magnets }\end{array}$ & - & - & 18.20 & & 6.14 & 1.31 & 0.53 & & 0.05 & - & - \\
\hline $\begin{array}{l}\text { Battery } \\
\text { alloys }\end{array}$ & 4.00 & 6.05 & 1.21 & 一 & 0.40 & - & - & 0.40 & & - & - \\
\hline $\begin{array}{l}\text { Phosphor } \\
\text { s }\end{array}$ & 0.99 & 0.77 & - & 6.23 & & - & 0.16 & - & 0.41 & 0.44 & - \\
\hline $\begin{array}{l}\text { Glass } \\
\text { polishing }\end{array}$ & $\begin{array}{r}10.7 \\
0\end{array}$ & 5.17 & - & & 0.57 & - & - & - & - & - & - \\
\hline Other & 2.9 & 1.43 & 1.13 & 1.43 & 0.30 & & 0.08 & 0.15 & - & - & 0.08 \\
\hline
\end{tabular}

Adapted from USGS 2011; many REOs are $~ 85 \%$ REE by mass.

A detailed breakdown for $\mathrm{Nd}$ uses is provided Table 8. The majority (67\%) of REPM uses are "motor-type" uses, including electric motors and generators, for example (Imarc 2016). Note that these estimates are from different sources and therefore show a range of estimated quantities used per application. The amounts used are expected to change, and generally increase, over time. Also note that although only electric vehicles are included here, internal combustion vehicles also use REE for air conditioning compressors, power steering motors, catalytic converters (La not Nd), and LCDs, and other applications; however, the amount per vehicle is $\sim 5 \%$ that of a similar electric vehicle (Xu, Yano, and Sakai 2016). The total amount of REE used in conventional vehicles in the United States is comparable to that used by electric vehicles, as conventional vehicles constitute $\sim 96 \%$ of the new-vehicle market in the United States (S. Constantinides, Arnold Magnetic Technologies, personal communication, 2016). The remaining uses of $\mathrm{Nd}$ are minor and include magnetic separation, magnetic resonance imaging machines, sensors, and energy storage (Imarc 2016). 
Table 8. Major End-Use Quantities of Nd

\begin{tabular}{lrr}
\hline Device & $\begin{array}{r}\text { Global Annual Use } \\
\text { of Nd (metric tons) }\end{array}$ & $\begin{array}{r}\text { Percent of Global } \\
\text { Production }\end{array}$ \\
\hline HDDs & $1,000-2,200$ & $4-8$ \\
cell phones & $500-700$ & $2.0-2.5$ \\
A/C compressors & $4,000+$ & 15 \\
electric vehicle & $1,440-2,600$ & $5-9$ \\
electric bicycles & $1,200-1,800$ & $4-7$ \\
wind turbines & $1,000-2,500$ & $4-9$ \\
acoustic transducers & 1,400 & 5 \\
\hline other motors & 6,600 & 24 \\
\hline
\end{tabular}

\footnotetext{
a Estimated to rise to $\sim 5,000$ metric tons per year by 2020 (S. Constantinides, Arnold Magnetic Technologies, personal communication, 2016).

Sources: De Lima and Filho 2015; S. Constantinides, Arnold Magnetic Technologies, personal communication, 2016; Clenfield, Yasu, and Biggs 2010; Zepf 2013; Hatch 2011; JARN 2015; Imarc 2016.
}

\subsection{Trade Flow}

The trade flow for REE is very complex. A thorough explanation of the global trade flow is not considered relevant to MCR production and is not included here. Rather, the focus here is on $\mathrm{Nd}$ trade flow starting from China, where most of it is mined. Also included here are examples of trade flow that convey a general understanding of how $\mathrm{Nd}$ is dispersed globally.

Figure 6 shows Chinese production of $\mathrm{Nd}$ ore, consumption of that ore, and subsequently derived materials and products, as well as export of $\mathrm{Nd}$ that is contained in the various products. The figure is important to understanding how much $\mathrm{Nd}$ stays in China versus being exported; it also important to understanding how much of the value and supply chains China controls for products that contain Nd. Even though only $25 \%$ of $\mathrm{Nd}$ produced in China is ultimately consumed in China, a substantial portion of Nd that is exported (37\%) either has already been incorporated into end products or has undergone some significant value addition, thereby capturing almost the entirety of the value added for those products. Exports of $\mathrm{Nd}$ metal ( $29 \%$ of exports) and $\mathrm{Nd}$ magnets (34\% of exports) do leave substantial value addition for other countries. However, as discussed in the previous section and shown in Figure 5, China has demonstrated willingness to curtail the availability of these materials to other countries to exert its influence. 


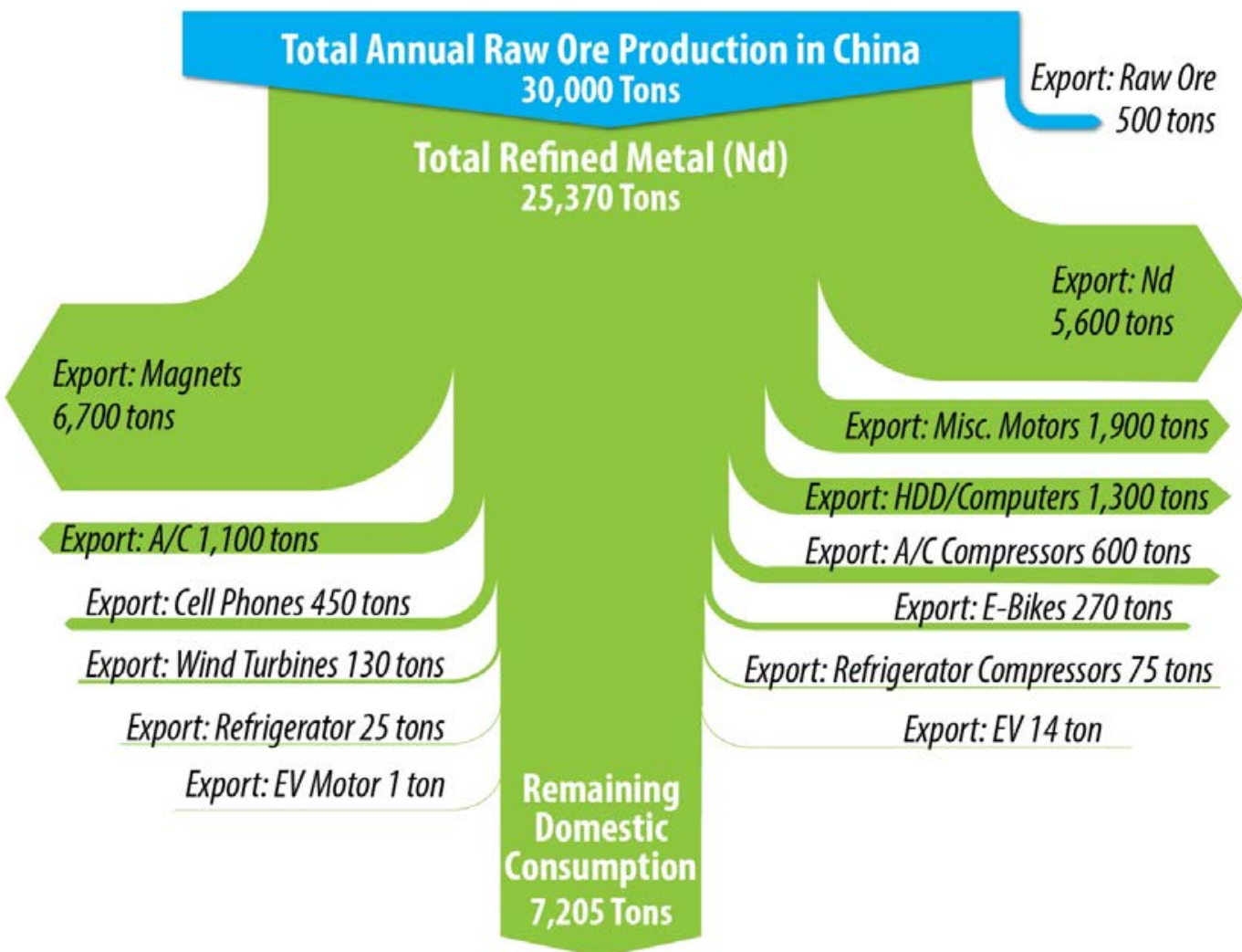

Figure 6. Chinese production, consumption, and exports of $\mathrm{Nd}$ in 2015

ITC 2016

Figure 7 shows what further trade could look like for end products produced in China that contain $\mathrm{Nd}$; in this example, cell phones are used. Although more than 1.6 billion cell phones are produced annually-almost $90 \%$ of which are produced in China (ITC 2016) - only 450 tons of $\mathrm{Nd}$ are required, which represents $1.8 \%$ of the refined $\mathrm{Nd}$ produced by China. Only the top six importing countries for cell phones from China are included in the figure for that sake of clarity.

Figure 8 (page 26) further shows how these countries export these phones. Some countries, such as Netherlands and the United Arab Emirates, are essentially shipping hubs for phones that are then re-exported to nearby countries. Other regions and countries, such as Hong Kong and South Korea, re-export to global markets. 


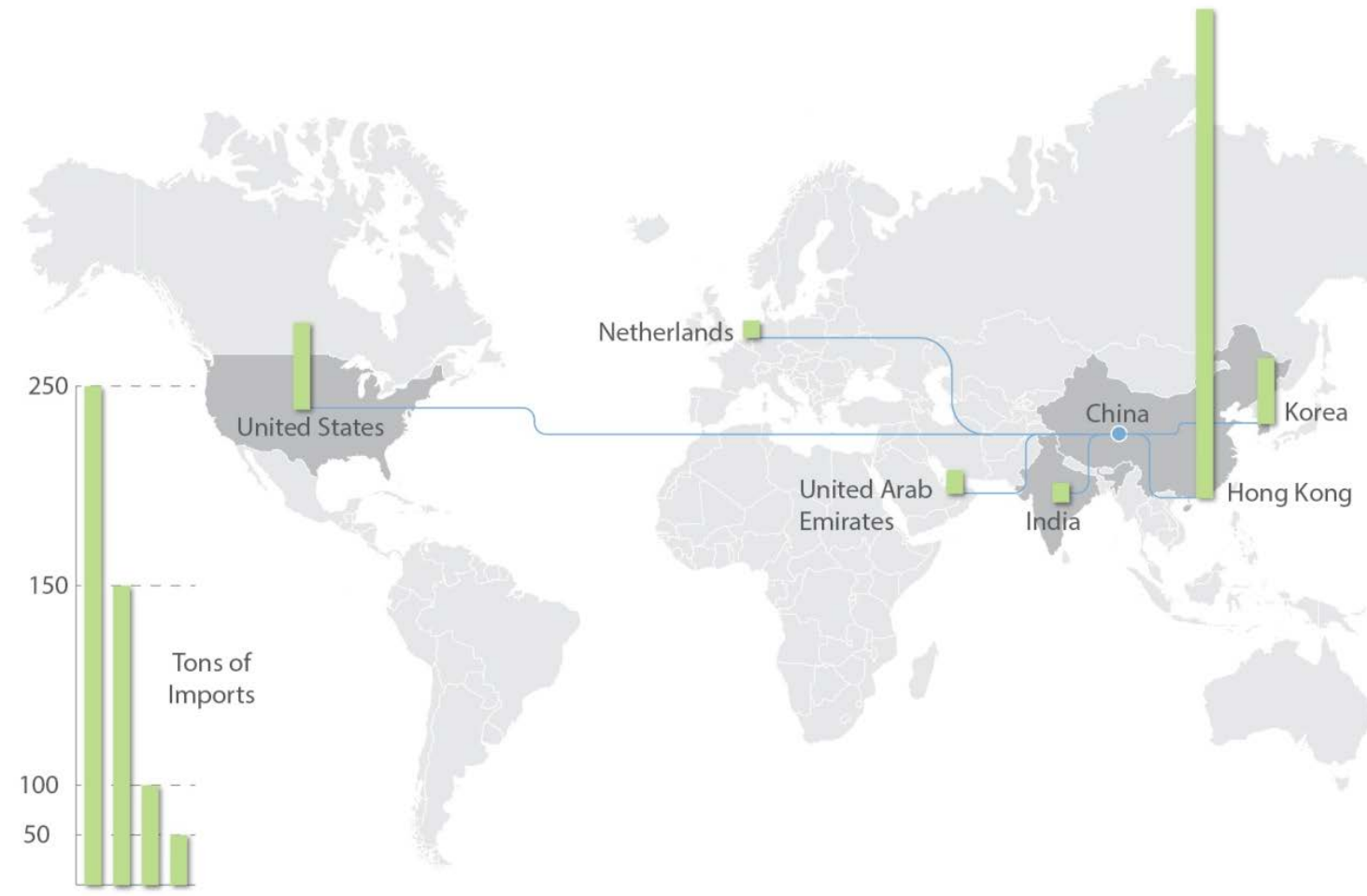

Figure 7. Example of trade flow out of China of cell phones

This is a representative example of the complexity of exports of $\mathrm{Nd}$ and products containing $\mathrm{Nd}$, and only the top six importing countries are listed.

Data source: ITC 2016.

Trade flows for other end-use products can be equally complex; they are not presented here because they do not alter the high-level conclusions that can be drawn about REE trade flow. The basic message to be gleaned from these data support those presented earlier in this report:

Most of the production of $\mathrm{Nd}$ (and all REE) is in China.

A substantial amount of the value addition of products containing $\mathrm{Nd}$ is in China.

There is widespread global trade of products containing Nd.

$\mathrm{Nd}$ is highly dispersed in products that are used over much of the world.

There is widespread access to end-of-life products containing $\mathrm{Nd}$.

The dispersed nature of $\mathrm{Nd}$ in these products make recycling a challenge. 


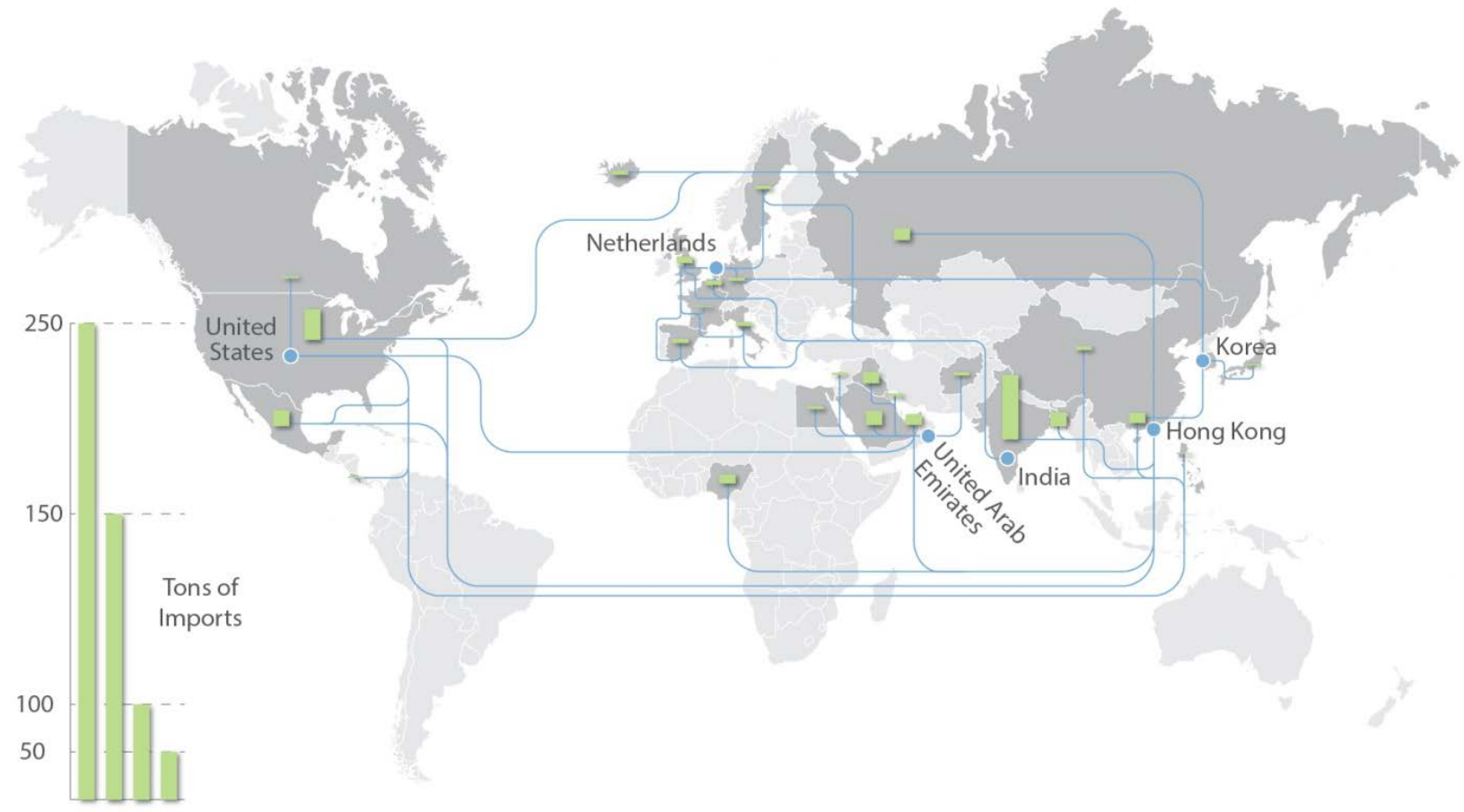

Figure 8. Re-exports of cell phones for major importing countries from China

Only the top few importing countries are listed.

Some countries, such as Netherlands and the United Arab Emirates, are essentially shipping hubs for phones that are then re-exported to nearby countries. Other countries, such as India and the United States consume much of what they import.

Data source: ITC 2016. 


\section{Impact of Qualitative Factors}

\subsection{Intellectual Property}

There is a substantial body of intellectual property surrounding rare earth mining, processing, and formulation for various compounds such as magnets, including 450 in the United States and more than 600 globally (Bloomberg News 2014). Table 9 shows the U.S. patent breakdown by approximate year of expiration as interpreted from the data compiled by the Critical Materials Institute (CMI 2016). Most of the patents are held by Japanese companies (417) with a large percentage of those held by Hitachi (123 in the United States). Hitachi acquired most of its portfolio by acquiring a large stake in Sumitomo Metal Industries (Hitachi 2003), which originally developed much of the original patent portfolio in the 1980 s.

Despite this large body of intellectual property and lawsuits attempting to protect it, a substantial and active black market exists for the production of REPMs. Eight companies have purchased licenses from Hitachi to produce magnets, but as many as 250 Chinese companies produce them illegally (Bloomberg News 2014). One estimate for the portion of REPMs produced on the black market is $\sim 35 \%$ (S. Constantinides, Arnold Magnetic Technologies, personal communication, 2016; S. Trout, Spontaneous Materials, personal communication, 2016). An additional difficulty in keeping the intellectual property out of the black market is that China is essentially the only source of REE for REPMs.

Table 9. U.S. Patents Related to Rare Earth Elements by Expiration Year

\begin{tabular}{rc}
\hline Expiration & Number of Patents \\
\hline$<2016$ & 90 \\
$2016-2019$ & 36 \\
$2020-2024$ & 144 \\
$2025-2029$ & 96 \\
$2030-$ & 86 \\
\hline
\end{tabular}

Source: Ames Laboratory 2016a

\subsection{Environmental Concerns}

EPA (2012) provides a detailed assessment of potential environmental impacts and summarizes the legacy impacts in China and the United States. EPA (2012) also identifies several potentially hazardous waste streams, but the main environmental risk is associated with the treatment and disposal of mine tailings.

Pan and Li provide a detailed literature search of REO mining and processing pollution with a case study of the Bayan Obo mine in Inner Mongolia. They looked at concentrations of heavy metals in soils in the mining and tailing areas, and they found substantial pollution in the form of cadmium, chromium, lead, copper, and zinc in levels that constituted overall moderate risk to local residents. Cadmium in particular is problematic, as it has by far the highest concentration of any of the metals and in many of the sample locations posed a "very high" potential ecological risk (Pan and Li 2016). 
Rare earth mining is also frequently associated with radioactivity, as many of the deposits contain thorium and/or uranium. This can be a serious problem, as such radioactive material can end up in mine tailings and leach into groundwater or become airborne particles; ${ }^{4}$ thus, special care must be taken and costs must be incurred to ensure proper containment. Recycling mitigates such concerns because no radioactive components are involved.

\subsection{Potential for Further Innovation}

The use of REPMs in clean energy technologies is particularly important because they may compete with MCR for materials. Although REPMs are very important for many of these technologies (e.g., electric cars, trucks, and bicycles, as well as wind turbines), these clean energy industries do not completely rely on REE. For example, direct drive REPM wind turbines represent $\sim 8 \%$ of the wind turbine market (De Lima and Filho 2015). Traditional wind turbines use asynchronous motors and gearboxes, which do not require REPMs. This wind industry is actively developing generators that do not depend on REPMs yet are still direct drive (to reduce weight and increase reliability); such generators include induction generators (Henriksen and Jensen 2011) and field wound synchronous motors, which are currently commercially available (Enercon 2016).

Similarly, the electric vehicle industry is actively developing motors that do not require permanent magnets or that reduce the amount of REE that is needed. For example, Tesla uses induction generators for its vehicles that do not use any REPMs (Rippel 2007). Honda and Daido Steel Co. jointly developed an EV traction motor that uses no Dy (Shanghai List 2016), whereas typical EV traction motors use 8\% (Rademaker 2013). And Hitachi Metals has developed a traction motor that uses less Dy without compromising temperature performance by diffusing Dy instead of direct alloying it (Widmer, Martin, and Kimiabeigi 2015).

Other industries are also making efforts to reduce the use of REPMs. For example, Gree makes an air conditioner compressor with no rare earth magnets, and it has sold more than 24 million units (JARN 2015). Ebm-Pabst has an electronically commutated DC motor design that uses ferrite magnets and has a peak efficiency of over 90\% (JARN 2013).

There is also a body of work and current or recent research on improving magnetocaloric materials. For example, Liu (2014) and Gschneidner, Pecharsky, and Tsokol (2005) summarize work in this area. This research focuses mainly on optimizing alloys for increased magnetocaloric effect, reducing hysteresis, creating materials with tunable Curie temperatures, and improving fabrication and workability of alloys. And the research includes La-, Mn-, and Gdbased alloys.

Research into magnetocaloric system improvements continues as well. Works such as Nielsen et al. (2013) and Engelbrecht and Pryds (2014) focus on aspects of system design and

\footnotetext{
${ }^{4}$ According to Emslander (2013), 12,000 tons of wastewater are created for each ton of REO.
} 
engineering, including regenerator heat transfer improvements, pressure drop reductions, and practical fabrication limitations.

DOE created the Critical Materials Institute, which "focuses on technologies that make better use of materials and eliminate the need for materials that are subject to supply disruptions" (CMI 2016). DOE also created CaloriCool, a materials research consortium, which will be looking at methods to improve on the efficiency of refrigeration technology by $20 \%-30 \%$ using caloric materials rather than vapor compression technology (Ames Laboratory 2016b).

The potential for REE processing improvement includes, for example, more complete extraction during beneficiation, which could improve yield by as much as 33\% (Sprecher et al. 2014) and improvements that could allow cost-effective reprocessing of existing mine tailings as a production alternative to developing new mines. Finally, expansion of recycling is certainly possible, with only $1 \%$ of REE being recycled currently.

The efforts outlined in this section show this is an active area for practical, industrial research and development that could lead to substantial cost reductions that might allow these activities to expand in the future. Such activities could also open the door to U.S.-based recycling or processing of certain REE that are present in domestic products. There is little evidence to suggest a substantial amount of REE processing could be located onshore; however, under certain circumstances, processes like that being developed at Infinium could allow for U.S.based activity in the recycling supply chain. 


\section{Conclusions and Insights}

Magnetocaloric cooling offers an innovative opportunity to increase the efficiency of refrigeration and building cooling over conventional vapor compression technologies. Eliminating the two-phase heat transfer refrigerants and compressor result in greater heat transfer efficiency, as well as a more simplified design with fewer moving parts. Though research on this technology is still in its early stages, analysis of the manufacturing and supply chain constraints can be used to guide research and development investment and planning toward areas that have the greatest likelihood of hindering market adoption. Based on prior work related to potential supply REE constraints (e.g., Bauer et al. 2011), this analysis focused on the impact of the availability and cost of permanent magnet and magnetocaloric materials.

The primary finding of this study is that the magnets used in MCR systems will continue to rely on rare earth, $\mathrm{Nd}$-based magnets for the foreseeable future. Though $\mathrm{Nd}$ is used in numerous applications and is not actually considered "rare," the vast majority of supply is produced and processed in China, resulting in unpredictable and potentially volatile availability and cost situations. Although REE could be mined in many places in the world, the highly distributed nature of the reserves and the relatively small size of most of the individual deposits reduce the potential impact they can have on global supply. Furthermore, without a critical mass of production and reserves outside China, developing large-scale processing facilities globally is difficult, thus further solidifying China's dominance in the REE industry.

Additionally, because of the increasing demand for REPM in clean energy technologies such as electric vehicles and wind turbines, as well as continued market growth for other products such as compressors, motors, hard disc drives, and electric bicycles, pressure on the availability and cost of REE for magnets is expected to increase. However, we estimate that significant demand for Nd-based REPM for MCR applications can be met while utilizing a moderate portion of production; $25 \%$ of the current global market for domestic refrigeration can be met with less than $13 \%$ of the annual production of $\mathrm{Nd}$.

Research is being conducted on separating and recycling $\mathrm{Nd}$ and other REE from consumer products, but separation and recycling been found to be prohibitively expensive compared to current mining and processing operations. However, as demand grows and recycling technology is improved, a larger supply of $\mathrm{Nd}$ and other REE could be made available.

With respect to the magnetocaloric materials themselves, $\mathrm{Gd}$ is the preferred and longeststudied material. Because the Curie temperature of $\mathrm{Gd}$ is near room temperature, $\mathrm{Gd}$ is particularly suitable for heat-pumping at temperatures needed for refrigeration and building cooling. However, Gd is a heavy REE that is produced in lower quantities and is typically expensive. La and $\mathrm{Mn}$ are thus being evaluated as alternatives to $\mathrm{Gd}$, particularly because their Curie temperatures can be adjusted through alloying. Though manufacturing of these materials is difficult because of their brittle nature, they are being extensively researched because of their greater availability and lower cost. 
Environmental considerations and the intellectual property landscape were also analyzed. As nearly all REEs for magnets are mined and processed in China, the impacts on the environment are largely regulated and realized there. Recycling technologies, should they become economic, would also have impacts on the environment and would be more geographically diverse. Most REE-related intellectual property, in the form of patents, is held by Japanese companies, which hold over $90 \%$ of the 452 U.S. patents still in force (CMI 2016). Notwithstanding the number of patents, it is estimated that a substantial portion of the global supply of REPM are from the black market.

Overall, this assessment found that material availability is important to the research and commercialization of MCR technology. In particular, REE for magnets may be limited at high levels of market penetration of MCR, especially as the demand for REPM in other clean energy technologies (e.g., electric motors) is expected to increase. However, the analysis found there is sufficient Nd supply for MCR technologies to replace a significant amount of the market currently held by conventional vapor compression cooling. Future analysis of market price estimates for different demand scenarios would help determine total market potential for MCR. Regarding magnetocaloric materials, global production of Gd is very small; however, alternative elements such as La and $\mathrm{Mn}$ are less expensive and produced in greater quantities. Research on tuning the Curie temperature and manufacturing of these alternatives could result in viable magnetocaloric systems. 


\section{References}

Ames Laboratory. 2016a. "Critical Materials Institute Announces Domestic Rare-Earth Magnet Partnership with Infinium." New release. https://www.ameslab.gov/news/newsreleases/critical-materials-institute-announces-domestic-rare-earth-magnet-partnership.

- - 2016b. "CaloriCool Launches Refrigeration Tech Research with First Meeting." News release. https://www.ameslab.gov/news/news-releases/caloricool-launches-refrigeration-techresearch-first-meeting.

AustralianRareEarths.com. "REE Resources-Reserves." Accessed October 2016: http://www.australianrareearths.com/known-rees-resources-reserves.html

Bandara, H. M. Dhammika, Mark A. Mantell, Julia W. Darcy, and Marion H. Emmert. 2015. "Closing the Lifecycle of Rare Earth Magnets: Discovery of Neodymium in Slag from Steel Mills." Energy Technol. 3: 118-120. https://doi.org/10.1002/ente.201402162

Barthel, Claus, and Thomas Götz. 2012. The Overall Worldwide Saving Potential from Domestic Refrigerators and Freezers: With Results Detailed for 11 World Regions. Wuppertal Institute for Climate, Environment and Energy. bigEE.

http://www.bigee.net/media/filer public/2012/12/04/bigee doc 2 refrigerators freezers wo rldwide potential 20121130.pdf.

Bauer, Diana, David Diamond, Jennifer Li, Michael McKittrick, David Sandalow, and Paul Telleen. 2011. U.S. Department of Energy Critical Materials Strategy. U.S. Department of Energy.

https://www.energy.gov/sites/prod/files/DOE CMS2011 FINAL Full.pdf.

Binnemans, Koen, Yiannis Pontikes, Peter Tom Jones, Peter, Tom Van Gerven, and Bart Blanpain. 2013. "Recovery of Rare Earths from Industrial Waste Residues: A Concise Review." 3rd International Slag Valorisation Symposium Leuven, Belgium, March 19-20, 2013.

Bjork, R, A. Smith, C. R. H. Bahl, and N. Pryds. 2011. "Determining the Minimum Mass and Cost of a Magnetic Refrigerator." Intl J of Refrigeration 34(8): 1805-1816.

https://doi.org/10.1016/j.ijrefrig.2011.05.021.

Bloomberg News. 2014 “China Taking on Hitachi as 17-Year-Old Patent Lapses.” http://www.bloomberg.com/news/articles/2014-07-28/china-taking-on-hitachi-as-17-year-oldrare-earth-patent-lapses.

Clancy, Heather. 2014. "Rare Earth Recycling Takes on New Luster." Forbes. February 25, 2014. http://www.forbes.com/sites/heatherclancy/2014/02/25/rare-earth-recycling-takes-on-newluster/\#5848e7462c00.

Clenfield, Jason, Mariko Yasu, and Stuart Biggs. 2010. "Hitachi Recycles Rare Earth as China Crimps Supply." http://www.bloomberg.com/news/articles/2010-12-08/hitachi-recycles-rareearth-as-china-crimps-supply. 
CMI (Critical Materials Institute). 2016. “U.S. Rare Earth Magnet Patents Table.”

https://cmi.ameslab.gov/resources/magnet-table.

Constantinides, Steve. 2015. "The Important Role of Dysprosium in Modern Permanent Magnets." Arnold Magnetic Technologies. Rev. 150903a.

https://www.arnoldmagnetics.com/wp-content/uploads/2017/10/Important-Role-of-

Dysprosium-in-Modern-Permanent-Magnets-150906.pdf.

Dent, Peter C. 2012. "Rare Earth Elements and Permanent Magnets (Invited)" J. Applied Physics 111. http://dx.doi.org/10.1063/1.3676616.

De Lima, Ismar Borges, and Walter Leal Filho. 2015. Rare Earths Industry: Technological, Economic, Implications. 1st ed. Elsevier.

DOE (U.S. Department of Energy). 2015. Critical Materials: Technology Assessment. Draft predecisional report. http://energy.gov/sites/prod/files/2015/02/f19/QTR\%20Ch8\%20\%20Critical\%20Materials\%20TA\%20Feb-13-2015.pdf.

Enercon. 2016. "WEC Components: Constant Innovation." Accessed 2016:

http://www.enercon.de/en/technology/wec-components/.

Engelbrecht, K., and N. Pryds. 2015. "Progress in Magnetic Refrigeration and Future Challenges." 6th IIF-IIR International Conference on Magnetic Refrigeration Environmental Implications. ISBN 978-0-12-802328-0, Victoria, BC, September 7-10, 2014.

EPA (U.S. Environmental Protection Agency). 2012. Rare Earth Elements: A Review of Production, Processing, Recycling, and Associated Environmental Issues. Environmental Protection Agency. EPA 600/R-12/572. https://nepis.epa.gov/Adobe/PDF/P100EUBC.pdf.

Evans, B., D. West, A. Mallow, and O. Abdelaziz. 2012. "Feasibility Analysis of Magnetic Refrigeration for Systems Having Over 35 Kw Cooling Capacity." ASHRAE 2012 Winter Conference, Chicago, IL.

Fraunhofer. 2015. "Recycling Permanent Magnets in One Go." Fraunhofer Research News. News release. https://www.fraunhofer.de/en/press/research-news/2015/september/recyclingpermanent-magnets-in-one-go.html.

Free, Kathryn. 2014. "The Future of Rare Earth Recycling: Companies Are Scrambling to Reuse Costly Rare Earth Elements." Scienceline. March 3, 2014. http://scienceline.org/2014/03/thefuture-of-rare-earth-recycling/.

Gómez, J. Romero, R. Ferreiro Garcia, J. Carbia Carril, and M. Romero Gómez. 2013. “A Review of Room Temperature Linear Reciprocating Magnetic Refrigerators." Renewable and Sustainable Energy Reviews 21: 1-12. https://doi.org/10.1016/j.rser.2012.12.018.

Gschneidner, K. A., V. K. Pecharsky, and A. O. Tsokol. 2005. "Recent Developments in Magnetocaloric Materials." Rep. Prog. Phys. 68: 1479-1539. http://dx.doi.org/10.1088/00344885/68/6/R04. 
Haque, Nawshad, Anthony Hughes, Seng Lim, and Chris Vernonl. 2014. "Rare Earth Elements: Overview of Mining, Mineralogy, Uses, Sustainability and Environmental Impact" Resources 3: 614-635. https://doi.org/10.3390/resources3040614.

Hatch, Gareth. 2011. "Seagate, Rare Earths and the Wrong End of the Stick." TMR (Technology Metals Research). July 23, 2011. Accessed 2016: http://www.techmetalsresearch.com/seagaterare-earths-and-the-wrong-end-of-the-stick/.

Henriksen, Matthew, and Bogi Bech Jensen. 2011. "Induction Generators for Direct-Drive Wind Turbines" In Proceedings of IEEE International Electric Machines and Drives Conference. IEEE. https://doi.org/10.1109/IEMDC.2011.5994759.

Hitachi. 2010. "Hitachi Develops Recycling Technologies for Rare Earth Metals." News release. http://www.hitachi.com/New/cnews/101206.pdf

Humphries, Marc. 2013. Rare Earth Elements: The Global Supply Chain. Congressional Research Service. R41347. https://www.fas.org/sgp/crs/natsec/R41347.pdf.

Imarc. 2016. Global Magnet Market: Industry Trends, Magnet Types, Major Markets, Manufacturing and Applications.

ISE (Institut für seltene Erden und strategische Metalle). "Aktuelle und Historische Marktpreise der Seltenen Erden und Strategischer Metalle." Accessed December 2016: https://institutseltene-erden.de/aktuelle-und-historische-marktpreise-der-gangigsten-seltenen-erden/.

ITC (International Trade Centre). "Trade Map.” Accessed November 2016:

http://trademap.org/Index.aspx.

Liu, Jian. 2014. “Optimizing and Fabricating Magnetocaloric Materials" Chin. Phys. B 23(4): 047503. https://doi.org/10.1088/1674-1056/23/4/047503.

JARN (Japan Air Conditioning, Heating and Refrigeration News). 2015. "Gree 'No-Rare-Earth' Compressor Awarded." April 17, 2015. https://www.ejarn.com/detail.php?id=34368.

- - . 2013. "External Rotor Motors Need No Rare Earth Magnets." August 22, 2013.

https://www.ejarn.com/detail.php?id=25749.

Kenji, Baba, Yuzo Hiroshige, and Takeshi Nemoto. 2013. "Rare-Earth Magnet Recycling." Hitachi Review 62(8): 452-455. http://www.hitachi.com/rev/pdf/2013/r2013 08 105.pdf.

Kitanovski, Andrej, Jaka Tušek, Urban Tomc, Uroš Plaznik, Marko Ožbolt, and Alojz Poredos. 2015. Magnetocaloric Energy Conversion: From Theory to Applications. Springer ISBN 978-3319-08741-2.

Kramer, M. J., R. W. McCallum, I. A. Anderson, and S. Constantinides. 2012. "Prospects for NonRare Earth Permanent Magnets for Traction Motors and Generators." JOM 64(7): 752-763. http://dx.doi.org/10.1007/s11837-012-0351-z. 
Lucas, Jacques, Pierre Lucas, Thierry Le Mercier, Alain Rollat, and William Davenport. 2015. Rare Earths: Science, Technology, Production and Use. Elsevier. ISBN:978-0-444-62735-3.

http://dx.doi.org/10.1016/C2012-0-02577-X.

Mineralprices.com. Accessed December 2016: http://www. mineralprices.com.

Mining-technology.com. "Scarce Supply: The World's Biggest Rare Earth Metal Producers."

Accessed December 2016: http://www.mining-technology.com/features/featurescarce-supply--the-worlds-biggest-rare-earth-metal-producers-4298126/.

Minter, Adam 2010. "Who's Surprised by the Rare Earth Embargo? Not Toyota."

Shanghai Scrap. http://shanghaiscrap.com/2010/09/whos-surprised-by-the-rare-earth-

embargo-not-toyota/.

MIT (Massachusetts Institute of Technology). "The Future of Strategic Natural Resources: Locations of Deposits: Finding and Defining Strategic Mineral Deposits." Accessed 2016: http://web.mit.edu/12.000/www/m2016/finalwebsite/solutions/deposits.html.

Mitsubishi Electric. 2014. "Newly Developed Automatic Dismantling Equipment Removes and Recovers Rare Earth Magnets in Just 30 Seconds."

http://www. mitsubishielectric.com/company/environment/ecotopics/rareearth/how/index.ht $\underline{\mathrm{ml}}$.

MMTA (Minor Metals Trade Association). “Gd: Gadolinium” and “La: Lanthanum.” Accessed December 2016: http://www.mmta.co.uk/metals/Gd, http://www.mmta.co.uk/metals/La

Momen, Ayyoub M. 2016. Magnetocaloric Refrigerator Freezer. U.S. Department of Energy, Building Technologies Office 2016 Peer Review.

https://energy.gov/sites/prod/files/2016/04/f30/32210b Momen 040616-1435.pdf

Moya, X., S. Kar-Narayan, and N. Mathur. 2014. "Caloric Materials Near Ferroic Phase Transitions." Nature Materials 13: 439-450.

http://www.nature.com/doifinder/10.1038/nmat3951.

Nielsen, K. K., C. R. H. Bahl. A. Smith, K. Engelbrecht, U. L. Olsen, and N. Pryds. 2013. "The Influence of Non-Magnetocaloric Properties on the Performance in Parallel-Plate AMRs." IntI J of Refrigeration 37: 127-134. http://dx.doi.org/10.1016/j.ijrefrig.2013.09.022.

ORNL (Oak Ridge National Laboratory). 2016. “ORNL Licenses Rare Earth Magnet Recycling Process to Momentum Technologies." https://www.ornl.gov/news/ornl-licenses-rare-earthmagnet-recycling-process-momentum-technologies.

Pecharsky, V. K., and K.A. Gschneidner. 1997. "Giant Magnetocaloric Effect in Gd5(Si2Ge2)." Phys. Rev. Lett. 78: 4494.

- - . 2007. "Advanced Materials for Magnetic Cooling." Material Matters 2.4(4). https://www.sigmaaldrich.com/content/dam/sigma-aldrich/articles/materialmatters/pdf/advanced-materials.pdf. 
POST (The Parliamentary Office of Science and Technology). 2011. "Rare Earth Metals" London: The Parliamentary Office of Science and Technology.

Rademaker, Jelle H., René Kleijn, and Yongxiang Yang. 2013. "Recycling as a Strategy against Rare Earth Element Criticality: A Systemic Evaluation of the Potential Yield of NdFeB Magnet Recycling." Environ. Sci. Technol. 47: 10129-10136.

Reisch, Marc S. 2011. "Rhodia, Umicore to Recycle Rare Earths." Chemical and Engineering News 89(26): 16. http://cen.acs.org/articles/89/i26/Rhodia-Umicore-Recycle-Rare-Earths.html.

Reuters. 2016. "The Electric Car Revolution Is Making These Investors Very Optimistic." October 5, 2016. http://fortune.com/2016/10/05/electric-car-revolution-investors-lithium-rareearth-metals/.

Rippel, Wally. 2007. “Induction Versus DC Brushless Motors.” Tesla. January 9, 2007. https://www.tesla.com/blog/induction-versus-dc-brushless-motors.

Schulze, Rita, and Matthias Buchert. 2016. "Estimates of Global REE Recycling Potentials from NdFeB Magnet Material" Resources, Conservation and Recycling 113: 12-27.

http://dx.doi.org/10.1016/j.resconrec.2016.05.004.

Scrap Metal Forum. "Break Down of a Hard Drive: Dismantling, Breaking Down and Maximizing Scrap." Accessed 2016: http://www.scrapmetalforum.com/dismantling-breaking-downmaximizing-scrap/3787-break-down-hard-drive.html.

SETIS (Strategic Energy Technologies Information System). European Commission. Accessed October 2016: https://setis.ec.europa.eu/.

Smith Stegen, Karen. 2015. "Heavy Rare Earths, Permanent Magnets, and Renewable Energies: An Imminent Crisis." Energy Policy 79: 1-8. https://doi.org/10.1016/i.enpol.2014.12.015.

Spectrum Scientific. 2012. "The Price of Rare-Earth Neodymium Magnets -Crash! Crash! Crash!" Spectrum Scientific's Store Blog. May 14, 2012. Accessed December, 2016:

https://spectrumscientifics.wordpress.com/2012/05/14/the-price-of-rare-earth-neodymiummagnets-crash-crash-crash/.

Sprecher, Benjamin, Yanping Xiao, Allan Walton, John Speight, Rex Harris, Rene Kleijn, Geert Visser, and Gert Jan Kramer. 2014. "Life Cycle Inventory of the Production of Rare Earths and the "Subsequent Production of NdFeB Rare Earth Permanent Magnets." Environ. Sci. Technol. 48: 3951-3958. https://doi.org/10.1021/es404596q.

Statista. "Smartphones Industry: Statistics and Facts." Accessed December 2016:

http://www.statista.com/topics/840/smartphones/.

Statista. "S Gadolinium oxide price worldwide from 2009 to 2025." Accessed November 2019: https://www.statista.com/statistics/450160/global-reo-gadolinium-oxide-price-forecast/. 
Technology Metals Research. 2015. "TMR Advanced Rare-Earth Projects Index." http://www.techmetalsresearch.com/metrics-indices/tmr-advanced-rare-earth-projectsindex/.

USGS (U.S. Geological Survey). 2016. Mineral Commodity Summaries 2015. U.S. Geological Survey. http://dx.doi.org/10.3133/70140094. ISBN 978-1-4113-4011-4.

Wang, Xibo, Yalin Lei, Jianping Ge, and Sanmang Wu. 2015. "Production Forecast of China's Rare Earths Based on the Generalized Weng Model and Policy Recommendations." Resources Policy 43: 11-18. https://doi.org/10.1016/j.resourpol.2014.11.002.

Widmer, J., R. Martin, and M. Kimiabeigi. 2015. "Electric Vehicle Traction Motors without Rare Earth Magnets." Sustainable Materials and Technologies 3: 7-13.

https://doi.org/10.1016/j.susmat.2015.02.001.

Xie, Feng Ting An Zhang, David Dreisinger, and Fiona Doyle. 2014. "A Critical Review on Solvent Extraction of Rare Earths from Aqueous Solutions." Minerals Engineering 56: 10-28.

https://doi.org/10.1016/i.mineng.2013.10.021.

Xu, Guochang, Junya Yano, and Shin-ichi Sakai. 2016. "Scenario Analysis for Recovery of Rare Earth Elements from End-of-Life Vehicles." J Mater Cycles Waste Manag 18: 469-482.

http://dx.doi.org/10.1007/s10163-016-0487-y.

Zhang, Yiying. 2013. "Peak Neodymium: Material Constraints for Future Wind Power Development." MS Thesis, Dept. of Earth Sciences, Uppsala University, Sweden.

Zepf, Volker. 2013. Rare Earth Elements: A New Approach to the Nexus of Supply, Demand and Use: Exemplified along the Use of Neodymium in Permanent Magnets. Springer Science and Business Media. ISBN 978-3-642-35458-8.

Zimm C., A. Jastrab, A. Sternberg, V. K. Pecharsky, K. Gschneidner Jr., M. Osborne, and I. Anderson. 1998. "Description and Performance of a Near-Room Temperature Magnetic Refrigerator." Adv. Cryog. Eng. 43 1759-1766. 


\section{Bibliography}

Baba, Kenji, Hiroshige Yuzo, and Takeshi Nemoto. 2013. "Rare-Earth Magnet Recycling." Hitachi Review 62 (8): 452-455.

Bauer, Diana, David Diamond, Jennifer Li, David Sandalow, Paul Telleen, and Brent Wanner. 2010. U.S. Department of Energy Critical Materials Strategy. U.S. Department of Energy.

http://dx.doi.org/10.2172/1000846.

Critical Materials Institute (CMI). n.d. https://cmi.ameslab.gov/about.

DiFrancesco, C., J. Hedrick, D. Cordier, and J. Gambogi. 2016. Rare Earth Statistics.

U.S. Geological Survey.

DOE (U.S. Department of Energy). 2016. “Rare Earth Element Resources.”

http://energy.gov/maps/estimated-rare-earth-reserves-and-deposits.

Du, Xiaoyue, and T. E. Graedel. 2011. "Global In-Use Stocks of the Rare Earth Elements: A First Estimate." Environ. Sci. Technol. 45(9): 4096-4101. https://doi.org/10.1021/es102836s.

Emslander, M. 2013. "Rare Earth Industry Supply Alternative" California State University, Sacramento, ENV 190A Thesis.

Firdaus. 2016. "Review of High-Temperature Recovery of Rare Earth (Nd/Dy) from Magnet Waste.” J Sustain. Metall. 2(4): 276-295. https://doi.org/10.1007/s40831-016-0045-9.

Golev, Artem, Margaretha Scott, Peter D. Erskine, Saleem H. Ali, Grant R. Ballantyne. 2014. "Rare Earths Supply Chains: Current Status, Constraints and Opportunities." Resources Policy 41: 52-59. https://doi.org/10.1016/j.resourpol.2014.03.004.

Hitachi Metals, Sumitomo Special Metals Co., and Sumitomo Metal Industries. 2003. "Hitachi Metals and Sumitomo Special Metals Form Strategic Business Alliance, Hitachi Metals also Acquires $32.9 \%$ of the voting rights of Sumitomo Special Metals from Sumitomo Metal Industries." June 20, 2003. New release. https://www.hitachi-

metals.co.jp/e/press/pdf/n030620e.pdf.

Japan Metal Bulletin. 2011. "Rare Earth International Market Prices Remarkably Weakening." December 27, 2011. Accessed December 2016: http://www.japanmetalbulletin.com/?p=19361.

Li, Ziwei. 2016. “Why We Need a New Motor Design Suited for Magnets Recycling?” European Training Network for the Design and Recycling of Rare-Earth Permanent Magnet Motors and Generators in Hybrid and Full Electric Vehicles (DEMETER). Blog post. May 30, 2016. http://etndemeter.eu/why-we-need-a-new-motor-design-suited-for-magnets-recycling/.

Modern Permanent Magnets-https://www.arnoldmagnetics.com/wpcontent/uploads/2017/10/Important-Role-of-Dysprosium-in-Modern-Permanent-Magnets150906.pdf= 
Pan, Yuxue, and Haitao Li. 2016. "Investigating Heavy Metal Pollution in Mining Brownfield and Its Policy Implications: A Case Study of the Bayan Obo Rare Earth Mine, Inner Mongolia, China." Environmental Management 57(4): 879-893. https://doi.org/10.1007/s00267-016-0658-6.

Standridge, Charles R., and Lindsay Corneal. 2014. Remanufacturing, Repurposing, and Recycling of Post-Vehicle-Application Lithium-Ion Batteries. Mineta National Transit Research Consortium, College of Business San José State University. MNTRC Report 12-20.

http://transweb.sjsu.edu/PDFs/research/1137-post-vehicle-Li-lon-recycling.pdf.

Tan, Kenneth. 2016. "Honda Develops Hybrid Motor without Heavy Rare Earth Metals, Reducing Reliance on China." Shanghai List.

http://shanghaiist.com/2016/07/15/honda no rare earth metals motor.php.

USGS (U.S. Geological Survey). 2014. Rare earth statistics in Kelly, Thomas D., and Grecia R. Matos, comps., Historical Statistics for Mineral and Material Commodities in the United States. U.S. Geological Survey Data Series 140. Accessed October 2016:

http://minerals.usgs.gov/minerals/pubs/historical-statistics/

UK Parliament. 2010. "Rare Earth Metals, January 2011." POST: Parliamentary Office of Science and Technology. January 1, 2010. http://www. parliament.uk/briefing-papers/POST-PN-368.

Goonan, Thomas G. 2011. Rare Earth Elements: End Use and Recyclability. Scientific Investigations Report 2011-5094. U.S. Department of the Interior, and U.S. Geological Survey. https://doi.org/10.3133/sir20115094.

Vodyanoy, Vitaly J., and Yuri Mnyukh. 2013. "The Physical Nature of "Giant" Magnetocaloric and Electrocaloric Effects." American Journal of Materials Science 3(5): 105-109.

DOI: 10.5923/j.materials.20130305.01. 


\section{Appendix. Identified Rare Earth Deposits}

Table A-1 shows identified rate earth deposits in various stages of development. It is adapted from (Technology Metals Research 2015).

Table A-1. Identified Rare Earth Deposits Worldwide

\begin{tabular}{|c|c|c|c|c|c|c|}
\hline Project & Country & $\begin{array}{l}M^{a} \\
(M t)\end{array}$ & $\begin{array}{l}\text { TREO } \\
\text { (wt } \%)\end{array}$ & $\begin{array}{l}\text { TREO } \\
\text { (Mt) }\end{array}$ & $\begin{array}{l}\text { In-Situ TREO } \\
\text { (US\$/t(MR)) }\end{array}$ & $\begin{array}{l}\text { Basket Price } \\
\text { (US\$/kg) }\end{array}$ \\
\hline Aksu Diamas & Turkey & 494.0 & 0.07 & 0.345 & 9.92 & 14.21 \\
\hline Araxá & Brazil & 28.3 & 4.21 & 1.190 & 487.38 & 11.58 \\
\hline Ashram Main & Canada & 239.7 & 1.90 & 4.549 & 255.86 & 13.48 \\
\hline Ashram Middle and Heavy Rare Earth Oxide & Canada & 9.4 & 1.61 & 0.151 & 272.59 & 16.89 \\
\hline Bear Lodge & United States & 57.9 & 2.68 & 1.553 & 396.15 & 14.78 \\
\hline Bokan & United States & 5.8 & 0.60 & 0.035 & 140.72 & 23.37 \\
\hline Brockmans & Australia & 36.2 & 0.21 & 0.076 & 65.09 & 31.00 \\
\hline Browns Range & Australia & 9.0 & 0.63 & 0.057 & 198.92 & 31.57 \\
\hline Buckton & Canada & 3433.5 & 0.03 & 0.878 & 4.95 & 19.38 \\
\hline Buckton South & Canada & 496.7 & 0.03 & 0.124 & 4.93 & 20.11 \\
\hline Charley Creek (JV) & Australia & 805.3 & 0.03 & 0.235 & 5.36 & 18.38 \\
\hline
\end{tabular}




\begin{tabular}{|c|c|c|c|c|c|c|}
\hline Project & Country & $\begin{array}{l}M^{a} \\
(M t)\end{array}$ & $\begin{array}{l}\text { TREO } \\
(w t \%)\end{array}$ & $\begin{array}{l}\text { TREO } \\
\text { (Mt) }\end{array}$ & $\begin{array}{l}\text { In-Situ TREO } \\
\text { (US\$/t(MR)) }\end{array}$ & $\begin{array}{l}\text { Basket Price } \\
\text { (US\$/kg) }\end{array}$ \\
\hline Charley Creek (JV) & Australia & 805.3 & 0.03 & 0.235 & 5.36 & 18.38 \\
\hline Clay-Howells & Canada & 8.5 & 0.73 & 0.062 & 118.82 & 16.30 \\
\hline Cummins Range & Australia & 4.9 & 1.74 & 0.085 & 221.24 & 12.71 \\
\hline Dubbo Zirconia Project & Australia & 73.2 & 0.89 & 0.651 & 146.85 & 16.50 \\
\hline Eco Ridge & Canada & 59.3 & 0.16 & 0.093 & 22.44 & 14.32 \\
\hline Elliott Lake Teasdale & Canada & 51.6 & 0.19 & 0.098 & 25.34 & 13.31 \\
\hline Foxtrot & Canada & 14.4 & 1.01 & 0.146 & 179.83 & 17.73 \\
\hline Glenover (JV) & South Africa & 10.4 & 2.13 & 0.221 & 393.93 & 18.48 \\
\hline Glenover (JV) & South Africa & 10.4 & 2.13 & 0.221 & 393.93 & 18.48 \\
\hline Grande-Vallée & Canada & 1209.6 & 0.05 & 0.606 & 7.97 & 15.91 \\
\hline Hoidas Lake & Canada & 2.8 & 2.40 & 0.068 & 377.56 & 15.72 \\
\hline Kangankunde & Malawi & 2.5 & 4.24 & 0.107 & 460.40 & 10.86 \\
\hline Kipawa & Canada & 27.1 & 0.39 & 0.107 & 83.66 & 21.19 \\
\hline Kutessay II & Kyrgyzstan & 18.0 & 0.26 & 0.047 & 78.01 & 30.15 \\
\hline
\end{tabular}




\begin{tabular}{|c|c|c|c|c|c|c|}
\hline Project & Country & $\begin{array}{l}M^{a} \\
(M t)\end{array}$ & $\begin{array}{l}\text { TREO } \\
(w t \%)\end{array}$ & $\begin{array}{l}\text { TREO } \\
\text { (Mt) }\end{array}$ & $\begin{array}{l}\text { In-Situ TREO } \\
\text { (US\$/t(MR)) }\end{array}$ & $\begin{array}{l}\text { Basket Price } \\
\text { (US\$/kg) }\end{array}$ \\
\hline Kvanefjeld & Greenland & 673.0 & 1.09 & 7.369 & 144.57 & 13.20 \\
\hline La Paz & United States & 128.2 & 0.04 & 0.056 & 8.58 & 19.49 \\
\hline Lavergne-Springer & Canada & 16.9 & 1.16 & 0.197 & 154.41 & 13.27 \\
\hline Lofdal & Namibia & 1.7 & 0.59 & 0.010 & 181.28 & 30.65 \\
\hline Milo & Australia & 187.0 & 0.06 & 0.115 & 9.42 & 15.27 \\
\hline Montviel & Canada & 266.6 & 1.45 & 3.878 & 185.38 & 12.74 \\
\hline Mount Weld Central Lanthanide Deposit & Australia & 14.9 & 9.73 & 1.454 & 1361.38 & 13.99 \\
\hline Mount Weld Duncan & Australia & 9.0 & 4.84 & 0.435 & 846.35 & 17.50 \\
\hline Mountain Pass & United States & 31.6 & 6.57 & 2.072 & 628.78 & 9.57 \\
\hline Mrima Hill High Grade & Kenya & 26.9 & 7.04 & 1.893 & 932.67 & 13.24 \\
\hline Mrima Hill Main & Kenya & 132.5 & 3.21 & 4.252 & 492.35 & 15.35 \\
\hline Nechalacho Basal & Canada & 125.7 & 1.43 & 1.799 & 305.14 & 21.33 \\
\hline Nechalacho Upper & Canada & 177.7 & 1.32 & 2.353 & 233.46 & 17.63 \\
\hline Ngualla & Tanzania & 41.7 & 4.19 & 1.748 & 519.34 & 12.39 \\
\hline
\end{tabular}




\begin{tabular}{|c|c|c|c|c|c|c|}
\hline Project & Country & $\begin{array}{l}M^{a} \\
(M t)\end{array}$ & $\begin{array}{l}\text { TREO }^{b} \\
\text { (wt } \%)\end{array}$ & $\begin{array}{l}\text { TREO } \\
\text { (Mt) }\end{array}$ & $\begin{array}{l}\text { In-Situ TREO } \\
\text { (US } \$ / \text { t(MR)) }\end{array}$ & $\begin{array}{l}\text { Basket Price } \\
\text { (US\$/kg) }\end{array}$ \\
\hline Niobec & Canada & 1058.6 & 1.73 & 18.363 & 242.34 & 13.97 \\
\hline Nolans & Australia & 55.9 & 2.59 & 1.450 & 393.24 & 15.16 \\
\hline Norra Kärr & Sweden & 31.1 & 0.61 & 0.188 & 139.87 & 23.12 \\
\hline Olserum & Sweden & 7.8 & 0.62 & 0.048 & 134.75 & 21.86 \\
\hline Round Top & United States & 905.9 & 0.06 & 0.573 & 13.82 & 21.87 \\
\hline Sarfartoq & Greenland & 8.3 & 1.72 & 0.143 & 242.64 & 14.12 \\
\hline Serra Verde & Brazil & 909.0 & 0.16 & 1.454 & 26.95 & 16.84 \\
\hline Songwe Hill & Malawi & 31.8 & 1.48 & 0.469 & 219.51 & 14.85 \\
\hline Sørensen & Greenland & 242.0 & 1.10 & 2.667 & 135.33 & 12.28 \\
\hline Steenkampskraal & South Africa & 0.7 & 14.00 & 0.093 & 2166.11 & 15.47 \\
\hline Storkwitz & Germany & 4.5 & 0.45 & 0.020 & 54.71 & 12.11 \\
\hline Strange Lake Enriched & Canada & 20.0 & 1.44 & 0.288 & 315.08 & 21.87 \\
\hline Strange Lake Granite & Canada & 472.5 & 0.87 & 4.118 & 175.08 & 20.09 \\
\hline Tanbreez & Greenland & 4300.0 & 0.65 & 28.058 & 119.92 & 18.38 \\
\hline
\end{tabular}




\begin{tabular}{|c|c|c|c|c|c|c|}
\hline Project & Country & $\begin{array}{l}M^{a} \\
(M t)\end{array}$ & $\begin{array}{l}\text { TREO }^{b} \\
(w t \%)\end{array}$ & $\begin{array}{l}\text { TREO } \\
\text { (Mt) }\end{array}$ & $\begin{array}{l}\text { In-Situ TREO } \\
\text { (US\$/t(MR)) }\end{array}$ & $\begin{array}{l}\text { Basket Price } \\
\text { (US\$/kg) }\end{array}$ \\
\hline Tantalus & Madagascar & 627.7 & 0.08 & 0.562 & 13.91 & 16.81 \\
\hline Two Tom & Canada & 40.6 & 1.18 & 0.480 & 163.60 & 13.84 \\
\hline Wigu Hill Twiga & Tanzania & 0.5 & 5.27 & 0.025 & 403.26 & 7.65 \\
\hline Xiluvo & Mozambique & 1.1 & 2.03 & 0.023 & 301.62 & 14.86 \\
\hline Yangibana (JV) & Australia & 6.8 & 1.52 & 0.103 & 234.59 & 15.40 \\
\hline Yangibana (JV) & Australia & 6.8 & 1.52 & 0.103 & 234.59 & 15.40 \\
\hline Zandkopsdrift (JV) & South Africa & 46.8 & 1.89 & 0.886 & 271.46 & 14.34 \\
\hline Zandkopsdrift (JV) & South Africa & 46.8 & 1.89 & 0.886 & 271.46 & 14.34 \\
\hline one 3 & Greenland & 95.3 & 1.16 & 1.106 & 139.85 & 12.05 \\
\hline
\end{tabular}

${ }^{a} \mathrm{MR}=$ measured reserves $\mathrm{Mt}=$ million metric ton

$\mathrm{b}$ TREO $=$ total rare earth oxide 